\title{
A biophysical model of $S$. aurita early life history in the northern Gulf of Guinea
}

\author{
Koné Vamara ${ }^{1,{ }^{*}}$, Lett Christophe ${ }^{2,6}$, Penven Pierrick ${ }^{3}$, Bourlès Bernard ${ }^{4}$, Djakouré Sandrine ${ }^{5}$
}

${ }^{1}$ Centre de Recherches Océanologiques (CRO), 29 Rue des Pêcheurs, BPV 18, Abidjan, Côte d'Ivoire

${ }^{2}$ Sorbonne Universités, UPMC Université Paris 06, IRD, Unité de Modélisation Mathématique et Informatique des Systèmes Complexes (UMMISCO), F-93143, Bondy, France

${ }^{3}$ Laboratoire d'Océanographie Physique et Spatiale (LOPS), Ifremer, UMR 6523,

CNRS/IFREMER/IRD/UBO, Plouzané, France

${ }^{4}$ Laboratoire d'Etudes en Géophysique et Océanographie Spatiales (LEGOS), UMR 5566,

CNES/CNRS/IRD/UPS, Toulouse, France

${ }^{5}$ Laboratoire de Physique de l'Atmosphère et Mécanique des fluides (LAPA-MF), Université Félix Houphouet Boigny

${ }^{6}$ UMR MARBEC, Station Ifremer de Sète, Avenue J. Monnet, 34203 Sète Cedex, France

* Corresponding author : Vamara Koné, email address : kvamara@hotmail.com

\begin{abstract}
:
S. aurita is the most abundant small pelagic fish in the northern Gulf of Guinea. Its reproduction and recruitment depend crucially on environmental conditions. We developed a biophysical model of $S$. aurita early life history by coupling offline an individual-based model with the regional oceanic modeling system (ROMS). We used this model to investigate the main factors driving variability in eggs and larval dispersal and survival in the northern Gulf of Guinea. Precisely, individuals were released from different spawning areas along the coast and tracked for a period of 28 days corresponding to their planktonic phase. Individuals that remained in the coastal recruitment areas at an age more than 7 days, at which they can supposedly actively retain themselves in a favorable area, were considered as recruited. Simulation results show the importance of the spawning areas around Cape Palmas and Cape Three Points where cyclonic eddies trap eggs and larvae along the coast, preventing their advection offshore by the Guinea Current. The spawning period also plays a key role in the recruitment success, with highest coastal retention obtained during the major upwelling period (July to September). We find that a second retention peak can occur during the minor upwelling period (February to March) when larval mortality due to temperature is included in the model. These results are in general agreement with knowledge of $S$. aurita reproduction in the northern Gulf of Guinea.
\end{abstract}




\section{Highlights}

- A biophysical model of $S$. aurita early life history in the northern Gulf of Guinea is proposed. The physical features are the main processes determining larval drift pathways and retention areas. The role played by cyclonic and anti-cyclonic eddies in coastal retention is emphasized. Two most favorable spawning periods during the minor and the major upwelling are simulated.

Keywords: hydrodynamic model, individual-based model, $S$. aurita early life stage, recruitment, upwelling, northern Gulf of Guinea

\section{Introduction}

Coastal upwelling is a dramatic event during which warm nearshore water is replaced by subsurface cold nutrient-rich water. The most prominent upwelling areas are located at the eastern boundaries of the world oceans. But important coastal upwellings also occur along the eastern part of the two capes (Cape Palmas and Cape Three Points, Fig. 1) in the northern Gulf of Guinea. In this particular area, upwelling events are unique in 
that they occur along a zonal coast, in contrast to the other eastern boundary upwelling regions where upwelling occurs along a meridional coast through Ekman pumping. In this particular upwelling system, $S$. aurita, one of the most abundant small pelagic fish in the region, has adapted its reproductive strategy to these particular environmental conditions (Binet and Marchal, 1993). The knowledge of small pelagic fish dynamics presents a particular interest both for understanding marine ecosystems functioning and for economical reasons. Indeed, clupeoids are believed to control the trophic dynamics of upwelling ecosystems (Cury et al., 2000) through the energy transfer from the first trophic levels to the top levels. Clupeoids represent $30 \%$ of the world's fish captures (Tacon and Metian 2009). However the large fluctuations in the abundance of small pelagic fishes due to environmental and anthropogenic forcing factors, and their relatively short life cycle, make these stocks particularly difficult to manage, and $S$. aurita is no exception.

Recruitment variability in marine fish has been an important issue in fishery science since it translates rapidly into fluctuations in the stock (Anderson 1988, Jacobson et al., 2001). Houde (2008) pointed out that recruitment variability can result from numerous processes operating at different time and space scales, and represents an integrated process acting throughout the pre-recruit life. Larval survival is a key issue for the recruitment process (Leggett and Deblois, 1994), and this survival is mediated by environmental constraints. Oceanic circulation determines the retention or transport of fish eggs and larvae in areas favorable for their growth and survival. This includes closed areas such as bays or island seas, and other areas favoring retention such as anticyclonic gyres or other features of convergent circulation, inshore versus offshore areas, tidally mixed areas of continental shelves, and frontal regions. 
Like in other upwelling systems, environmental conditions were shown to be important for the abundance and availability of small pelagic fish in the northern Gulf of Guinea (Pezennec and Bard, 1992). Some authors suggested that a single stock supported the whole yield of S. aurita (Binet, 1988; Binet and Marchal., 1993). Based on tagging experiments, a population spawning in the vicinity of Cape Three Points during the major upwelling season (boreal summer) was identified. However, from plankton surveys conducted between Cape Palmas and Cape Three Points from 1969 to 1972, Marchal (1991) pointed at a second population eastward of Cape Palmas during the minor upwelling season.

Sampling the sea at an appropriate frequency, and at time and space scales required to evaluate mechanisms controlling fish recruitment variability, presents formidable financial, technical, and logistical challenges. As a complement to field studies, numerical modeling has become an essential and valuable component of research. In particular, the approach based on biophysical models has had notable success in providing new insight on recruitment variability (Houde, 2008).

This paper is the first development and use of a biophysical model applied on the northern Gulf of Guinea upwelling area. We first present the physical and biological components of the model. We then use this model to study how hydrodynamic conditions impact $S$. aurita eggs and larval dispersal and survival from their spawning areas to their nursery grounds. The simulated patterns are finally discussed in relation to observed spatial and seasonal spawning patterns and to the state of knowledge in the region.

\section{MATERIAL AND METHODS}

\subsection{Hydrodynamic model}


The hydrodynamic model used is the Regional Ocean Modeling System (ROMS) (Shchepetkin and McWilliams, 2005), which is a split-explicit, free-surface oceanic model discretized in coastline- and terrain-following curvilinear coordinates. It is based on the Boussinesq approximation and on the hydrostatic balance. Short time-steps are used to advance the barotropic momentum equations and longer time-steps are used to solve the baroclinic momentum equations. In order to maximize computing efficiency, the simulation employs the two-way embedding capability of ROMS-AGRIF (Debreu and Mazauric, 2006; Debreu and Blayo, 2008; Debreu et al., 2012). Such a method allows the outputs from the lower resolution 'parent' domain to provide boundary conditions for the higher resolution 'child' domain nested within it and the 'child' domain in turn feeds the parent domain. The ROMSTOOLS package (Penven et al., 2008 ) is used for the design of our configuration. The model configuration is built over the Tropical Atlantic with a nested high resolution zoom focusing on the northern Gulf of Guinea (Fig. 1). The parent domain spans $65.2^{\circ} \mathrm{W}-15^{\circ} \mathrm{E}$ and $10^{\circ} \mathrm{S}-14^{\circ} \mathrm{N}$ and has a horizontal resolution of $\frac{1^{\circ}}{5}$ (i.e., $\sim 22 \mathrm{~km}$ ). The high resolution-child model is designed to encompass most of the northern Gulf of Guinea upwelling area and has a temporal and spatial resolution 3 times finer than the parent grid. It spans $12.33^{\circ} \mathrm{W}-11.73^{\circ} \mathrm{E}$ and $3.98^{\circ} \mathrm{S}-8.05^{\circ} \mathrm{N}$ with a horizontal resolution of $\frac{1^{\circ}}{15}($ i.e., $\sim 7 \mathrm{~km})$. Both the parent and child grids have 45 sigma levels that are stretched so that near-surface resolution increases. The model topography was built using the 1' GEBCO (General Bathymetric Chart of the Oceans: http://www.gebco.net) product. At the surface, the model is forced with a monthly wind stress climatology derived from SCOW (Scatterometer Climatology of Ocean Winds) and available from September 1999 to August 2007 (Risien and Chelton, 2008). The surface heat and freshwater fluxes introduced in the model are monthly fields derived from Comprehensive Ocean Atmosphere Data Set (COADS) (Da Silva et 
al., 1994). Our model configuration has three open boundaries (South, West, and North) forced by the World Ocean Atlas 2009 (WOA09) monthly climatology.

The model was run during 10 years and outputs were stored every 2 days (Djakouré et al., 2014). A statistical equilibrium is reached after 4 years of spin-up. The results presented here were averaged from year 6 to year 10 of the simulation.

\subsection{Biophysical model}

The biophysical model used in this study is based on the model developed by Mullon et al. (2003) and later by Lett et al. (2008), known as Ichthyop. It uses the virtual environment simulated by the high-resolution child hydrodynamic model to transport individuals passively. This virtual environment is characterized by water velocity fields (zonal (u), meridional (v) and vertical (w) components), and temperature (T) stored every 2 days. Transport of individuals relies on advection and horizontal dispersion as proposed by Peliz et al. (2007). Ichthyop has been extensively used to study the impact of environmental factors on the recruitment success of small pelagic fish (sardine and anchovy) in the main eastern boundary currents, including the Benguela upwelling system to study the transport of the anchovy eggs and larvae from the spawning area over the Agulhas Bank to the nursery area along the west coast of South Africa (Parada et al., 2003, 2008; Lett et al. 2007a; Koné et al.2013), the Humbolt upwelling system

(Lett et al., 2007b; Brochier et al., 2008) and the Canary upwelling system (Brochier et al., 2009, 2011). Recently it has also been used in the Senegalese-Mauritanian upwelling region to study retention success of $S$. aurita (Mbaye et al., 2015). Our Gulf of Guinea configuration of Ichthyop initially contains 5000 eggs (particles) randomly released within the different spawning areas, defined according to field observation of $S$. aurita distribution (Boely and Fréon, 1979; Binet, 1982, 1988; Roy et al., 1989). 
Precisely, six spawning areas were defined: Cape Palmas inshore $\left(\mathrm{CaP}_{\text {in }}\right)$ between the isobaths 0-1200 m, Cape Palmas offshore ( $\left.\mathrm{CaP}_{\text {off }}\right)$ between the isobaths 1200-2000 m, Cape Three Points inshore (CaTPin) between the isobaths 0-1200 m, Cape Three Points offshore $\left(\mathrm{CaTP}_{\text {off }}\right)$ between the isobaths 1200-2000 m, Mid-East Gulf of Guinea inshore between the isobaths $0-1200 \mathrm{~m}\left(\mathrm{MEGG}_{\mathrm{in}}\right)$, and the inshore area of the North-East Gulf of Guinea $\left(\mathrm{NEGG}_{\mathrm{in}}\right)$ between the isobaths 0-1200 m (Fig. 2a). Particles were released throughout the year at the beginning of each month. Like in previous modeling works conducted in the Benguela (Mullon et al. 2003; Parada et al. 2003; Koné et al. 2013), the putative effects of spawning depth on larval dispersal and survival were studied by considering three release depth levels (0-25 m, 25-50 m and 50-75 m). Similarly the effects of hot lethal temperature for eggs and larvae were studied by considering three values $\left(22^{\circ} \mathrm{C}, 25^{\circ} \mathrm{C}\right.$ and $\left.28^{\circ} \mathrm{C}\right)$ based on Conand (1977) who pointed out that $S$. aurita optimal spawning conditions were ranging from $22^{\circ}$ to $25^{\circ} \mathrm{C}$. In the following, we refer to the simulation with hot lethal temperature $>=22^{\circ},>=25^{\circ}$ and $>=28^{\circ} \mathrm{C}$ as SHT22, SHT25 and SHT28, respectively.

To be considered as recruited in the model, individuals had to be located within the recruitment area defined along the coast (Fig. 2b) and aged between 7 days (the average age at which they can supposedly actively retain themselves in a favorable area: Ditty et al., 1994), and 28 days (average planktonic larval duration, M'Baye et al., 2015).

\subsection{Data}

Satellite and in situ data were used to evaluate the ability of our hydrodynamic model to reproduce the main features of the northern Gulf of Guinea upwelling system.

The model Sea Surface Temperature (SST) was compared to: (i) World Ocean Atlas 2009 (WOA09), (ii) MODerate resolution Imaging Spectroradiometer (MODIS) from 
the AQUA satellite of the National Aeronautics and Space Administration (NASA) with a spatial resolution of $4 \mathrm{~km}$ and (iii) Reynolds (Reynolds et al. 2007) climatologies.

The model mean circulation was compared to the observed surface current climatology product of Lumpkin and Garrafo (2005) and Lumpkin and Johnson (2013) available at (www.aoml.noaa.gov/phod/dac/drifter_climatology.html). This product is based on near-surface velocities from satellite-tracked drogue drifter buoys. The monthly mean climatology data is gridded at a $\frac{1^{\circ}}{2} \times \frac{1^{\circ}}{2}$ resolution.

The model Mixed Layer Depth (MLD) was evaluated against the monthly climatology of MLD for the global ocean of de Boyer Montégut et al., (2004) computed from in situ measurements of temperature and salinity. In the model, MLD was evaluated using the routine proposed by Lorbacher et al., (2006) implemented in the ROMSTOOL package (Penven et al., 2008).

\section{RESULTS}

\subsection{Evaluation of the hydrodynamic model solution}

The ROMS simulation used in this study is the same as the one performed by Djakouré et al. (2014) to study the properties, the generation process and the effects of coastal cyclonic eddies on the coastal upwelling observed in the northern Gulf of Guinea. In addition to their validation effort of the model, we here focus our evaluation on the seasonal variability of temperature, surface currents and mixed-layer depth, which are crucial variables that determine the fate of individuals in our biophysical model.

\subsubsection{Sea surface temperature}

Winter (January to March) and summer (July to September) distributions of Sea Surface Temperature (SST) simulated by the model are compared to SST derived from WOA09 
(Fig. 3). Winter and summer were chosen since they are separated enough in time to cover the overall temporal variability of the SST distribution. The contrast between these two extreme seasons is strong enough to emphasize the main seasonal features of the northern Gulf of Guinea ecosystem. During winter (Fig. 3 left), warm SSTs ( $28^{\circ} \mathrm{C}-30^{\circ} \mathrm{C}$ ) are simulated in the whole northern Gulf of Guinea from $6^{\circ} \mathrm{N}$ to the equator, except in coastal areas, in the vicinity of the two capes (Cape Palmas and Cape Three Points) and below the Equator where the model simulates cooler SSTs $\left(\sim 26^{\circ} \mathrm{C}\right.$ $27^{\circ} \mathrm{C}$ ). These patterns are consistent with those derived from WOA09 data. However, a warm bias of $\sim 0.5^{\circ} \mathrm{C}$ is noticeable for the model in the warm SSTs region, while the model displays a cold bias of $\sim 0.5^{\circ} \mathrm{C}$ to $1^{\circ} \mathrm{C}$ in the colder regions. Cooler SSTs are observed along the capes signature of the minor upwelling (Arfi et al., 1991; Wiafe et al., 2008). The warm SSTs are propagated eastward by the North Equatorial Counter Current and the Guinea Current (Hisard and Merle, 1980; Stramma and Schott, 1999).

During summer (Fig. 3 right), cold SSTs $\left(\sim 24^{\circ} \mathrm{C}\right)$ are simulated both in the coastal area (off Cape Palmas and Cape Three Points) and south of $2^{\circ} \mathrm{N}$ where we can see the signature of the equatorial Atlantic Cold Tongue (ACT) propagating westward as described by Marin et al. (2009). From $4^{\circ} \mathrm{N}$ to $2^{\circ} \mathrm{N}$, the model simulates warmer water $\left(\sim 26-27^{\circ} \mathrm{C}\right)$ which is transported eastward by the Guinea Current. These results are consistent with data, except for a cold bias of $\sim 1^{\circ} \mathrm{C}$ in the coastal upwelling region and a warm bias of $\sim 0.8^{\circ} \mathrm{C}-1^{\circ} \mathrm{C}$ between $4^{\circ} \mathrm{N}-1^{\circ} \mathrm{S}$ and $12^{\circ} \mathrm{W}-0^{\circ} \mathrm{E}$. The model tends to overestimate upwelling near the coast compared to WOA09 data, presumably because of the coarse spatial resolution of the latter (Djakouré et al., 2014). But these warm and cold SST biases are in the range simulated in other upwelling systems using similar models (Veitch et al., 2009; Wahl et al., 2009). 
Fig. 4 shows the temporal evolution of SST averaged over the three inshore spawning areas and compared to different SST products (WOA09, MODIS, Reynolds). Both the model and the observations display an increase of SST from January to April (Fig. 4a) even until May (Fig. 4b,c) and a decrease from April to August where the SST reaches its minimum. The major upwelling period occurs from July to September where the coldest SSTs are observed. This is consistent with established knowledge (Bakun, 1978; Verstraete, 1992; Hardman-Mountford and McGlade, 2003). The minor upwelling is simulated by ROMS in March in the area around Cape Palmas. This minor upwelling is not visible in data products.

\subsubsection{Surface zonal currents}

The average surface zonal velocities for winter and summer are shown over the whole Tropical Atlantic basin (Fig. 5). For both seasons, the main features of the circulation i.e., the pathways and the spatial variability, are well reproduced. The main components of the circulation exhibit surface velocity cores signatures of the westward South Equatorial Current (SEC), the northwestward North Brazil Current (NBC), the westward North Equatorial Current (NEC) north of $10^{\circ} \mathrm{N}$, and the eastward North Equatorial Countercurrent (NECC) and Guinea Current (GC). All these major currents are visible both in the model and data, consistent with previous studies (Bourlès et al., 1999; Stramma and Schott, 1999; Schott et al., 2004). During winter, the northern (nSEC) and southern (sSEC) branches of the SEC are clearly visible around $2^{\circ} \mathrm{N}$ and $2^{\circ} \mathrm{S}$ respectively in both the model and data. The velocity simulated is $\sim 0.3 \mathrm{~m} . \mathrm{s}^{-1}$, similar to the measured velocity of the nSEC given by Bourlès et al., (1999), whereas it is $\sim 0.5 \mathrm{~m} . \mathrm{s}^{-1}$ from NOAA drifters. The northwestward NBC is located along the coast of Brazil between $5^{\circ} \mathrm{S}$ to $10^{\circ} \mathrm{N}$ in the model, in good agreement with data. Its maximum simulated velocity is about $1 \mathrm{~m} . \mathrm{s}^{-1}$ whereas in NOAA drifters it is about $0.8 \mathrm{~m} . \mathrm{s}^{-1}$. These 
velocities are in the same order of magnitude as those described by Bourlès et al., (1999) and Schott et al., $(1998,1999)$. Between $5^{\circ} \mathrm{N}$ to $10^{\circ} \mathrm{N}$, the $\mathrm{NBC}$ retroflects and feeds the eastward NECC fully developed in summer in both the model and data. The velocity simulated is in the same range of the one derived from data $\left(\sim 0.3 \mathrm{~m} \cdot \mathrm{s}^{-1}\right)$.

During winter, when the NBC retroflection is remnant (Bourlès et al., 1999), there is no direct connection between the NECC and the GC. The GC is visible in the northern Gulf of Guinea with a maximum velocity of $0.5 \mathrm{~m} . \mathrm{s}^{-1}$ around Cape Palmas in good agreement with data.

During summer, the connection between the NECC and the GC is well established. The velocity of the NECC increases $\left(\sim 0.5 \mathrm{~m} . \mathrm{s}^{-1}\right)$ compared to winter, and the NECC feeds the GC which flow also increases. The maximum simulated velocity of the GC in the vicinity of Cape Palmas is $\sim 1 \mathrm{~m} . \mathrm{s}^{-1}$, in good agreement with data. This is also consistent with the results of Arnault (1987) and Richardson and Reverdin (1987) and the previously described GC seasonal cycle, minimum during winter and maximum during summer (Bakun, 1978; Richardson and Philander, 1987; Colin, 1988). In summer, the seasonal variability of the intensity of the two branches of the SEC (nSEC and sSEC) is less pronounced both in the model and data. The main change concerns the spatial extension of the sSEC which is sparser than in winter. Conversely, the NBC seasonal variability is relatively marked reaching its maximum during summer.

\subsubsection{Mixed layer depth}

In this section, we examine spatial and temporal characteristics of the mixed layer depth (MLD) over the child grid domain (Fig. 6). The capability of the model to reproduce correctly the spatial patterns of MLD and its temporal evolution is of particular importance. Indeed, the seasonality of MLD modulates the nutrient supply and hence 
the plankton growth rate. Upwelling brings up cold water from the subsurface layers resulting in a shallow thermocline which in turn leads to a shoaling of MLD in the region of occurrence. So MLD variability can be seen as a signature for upwelling variability in the region. During winter (Fig. 6, left panels), the model simulates a shallow MLD all along the coast with values less than $20 \mathrm{~m}$, mostly $\sim 10-15 \mathrm{~m}$. The model simulates a relatively deep MLD between $2^{\circ} \mathrm{N}-2^{\circ} \mathrm{S}$ from the western boundary to $5^{\circ} \mathrm{E}$ with maximum value of $\sim 30 \mathrm{~m}$. These results are in good agreement with data (de Boyer Montégut et al., 2004). However, the model seems to underestimate MLD in the coastal region. During summer (Fig. 6, right panels), MLD is still shallow along the coast both in the model and data. As for the winter situation, this shallowing is overestimated in the model. The inshore/offshore gradient is well established. Both model and data depict a MLD deepening in the region between $2^{\circ} \mathrm{N}-6^{\circ} \mathrm{N}$ from the western boundary to $5^{\circ} \mathrm{E}$, where the GC is present. The contrast between the two seasons is well pronounced both in the model and data. Our results are also supported by the study of Berger et al. (2014) who highlighted similar features for MLD.

The evaluation of the hydrodynamic model with various data sets has shown that this model is able to simulate the main characteristics of the northern Gulf of Guinea physical environment reasonably well. The outputs of this model are then used as the forcing factors for the biophysical model.

\subsection{Effect of spawning area on larval retention}

Fig. 7 illustrates the simulated dispersal of individuals initially released within $S$. aurita spawning ground (Fig. 7a). After 8 days, individuals are mostly disseminated along the coast by the flow (Fig. 7b). This dispersal continues between 16 days (Fig. 7c) and 28 days when individuals are widely disseminated in the model basin with some of them 
ending far from the coast (Fig. 7d). It is clear from this example that hydrodynamic features are major processes determining larval drift pathways and their retention along the coast, with visible areas of cyclonic circulation and flow divergence.

The mean percentage of coastal retention obtained from the six different spawning areas considered in our simulations (Fig. 2), are shown in Fig. 8a, b and c. The maximum retention levels are obtained for individuals released in the inshore part of the zones centered on Cape Palmas $\left(\mathrm{CaP}_{\text {in }}\right)$ and Cape Three Points $\left(\mathrm{CaTP}_{\text {in }}\right)$ with $\sim 25 \%$ and $40 \%$ of them staying in the recruitment area for SHT22 and SHT25, respectively. These maximum values are followed by the corresponding offshore areas $\left(\mathrm{CaTP}_{\text {off }}\right.$ and $\left.\mathrm{CaP}_{\text {off }}\right)$ for SHT22 (Fig. 8a), and by $\mathrm{CaTP}_{\text {off }}$ and $\mathrm{MEGG}_{\text {in }}$ for SHT25 (Fig. 8b). The lowest retention value is obtained for $\mathrm{NEGG}_{\text {in }}$, with $\sim 10 \%$ and $\sim 20 \%$ for SHT22 and SHT25, respectively. For SHT28 simulation, the maximum retention values are obtained for inshore zones $\left(\mathrm{CaP}_{\mathrm{in}}, \mathrm{CaTP}_{\mathrm{in}}\right.$, and $\left.\mathrm{MEGG}_{\text {in }}\right)$ with $\sim 70 \%$ of retained individuals. The minimum retention value is obtained for $\mathrm{CaP}_{\text {off }}$, followed by $\mathrm{NEGG}_{\text {in }}$. The overall values of retention increase with the lethal temperature threshold.

\subsection{Seasonal variability in drift patterns}

Fig. 9 shows the monthly drift routes of larvae obtained from the biophysical model for a typical simulation year. For most months, three main drift patterns are noticeable: alongshore drift westwards, coastally trapped eddies (two cyclonic east of Cape Palmas and Cape Three Points, respectively, and one anti-cyclonic off the NEGGin area in the Niger delta region), and offshore advection (particularly off the Niger delta). These patterns intensify seasonally, in particular the offshore advection is stronger in MayAugust, and the western cyclonic eddy is more consistent from August to November.

\subsection{Effect of spawning period on larval retention}


Fig. 9a, b and c depict the time evolution of the mean simulated retention for different spawning periods. Interestingly, the seasonal variability of retention has two maximum in both SHT22 and SHT25 simulations. The first maximum occurs in February, i.e. during the minor upwelling, and thereafter retention decreases and reaches its minimum in May. The second maximum, more pronounced, is obtained during the major upwelling period, with a peak in August. In the SHT28 simulation, retention has one peak only, during the major upwelling period.

\subsection{Effect of spawning depth on larval retention}

The simulated retention increases with depth from 0-25 $\mathrm{m}$ to 50-75 $\mathrm{m}$ in both SHT22 and SHT25 (Fig. 10 a, and b), whereas in SHT28 there is hardly any difference between the 25-50 $\mathrm{m}$ and 25-75 $\mathrm{m}$ depth levels. The minimum retention is obtained for particles released in the surface layer $(0-25 \mathrm{~m})$ in all the simulations.

Although not being the main goal of this study, we also analyzed the impact of the year of release on the simulated retention in Appendix A. The interannual variability of simulated retention is very weak in all simulations (SHT22, SHT25, and SHT28; Fig. A1).

\subsection{The sensitivity analysis}

A multifactor analysis of variance performed on the retention values showed that the Area, Month and Depth variables explain more than $77 \%, 78 \%$ and $49 \%$ of the variance of the model in SHT22, SHT25 and SHT28 simulations, respectively (Tables 1, 2 and 3). The importance of these variables in the model is detailed in the core of the manuscript. Three important first order interactions were observed: Area*Month, Area*Depth and Month*Depth, with more than 15\%, 13\% and $35 \%$ of the explained variance in SHT22, SHT25 and SHT28, respectively. 


\section{Discussion}

The recruitment of $S$. aurita in the northern Gulf of Guinea ecosystem is constrained by the hydrodynamic features which determine their retention along the coast. The highest retention value obtained for $\mathrm{CaTP}_{\text {in }}$ in all simulations concurs with the finding of Boely and Fréon (1979) and Roy et al. (1989) who identified this region as the main spawning ground for S. aurita. According to Binet $(1982 ; 1988)$, most reproduction of S. aurita takes place between Cape Palmas and Cape Three Points. Indeed, this author established that the stock of the spawning population extended from Cape Palmas to Cape of Three Points, suggesting that reproduction took place in this area. The link between the spatial distribution of a spawning population and egg distribution is supported by Houde (2008) who stated that adult stock abundance plays a role in controlling and regulating recruitment through stock fecundity, egg quality, and via density-dependent effects. Besides, during a series of monthly sampling of ichthyoplankton realized from July 1969 to April 1972, Krzelj (1972) and later Binet and Marchal (1993) and Marchal (1993), identified two spawning areas centered on the two capes. $\mathrm{CaP}_{\text {in }}$ and $\mathrm{CaTP}_{\text {in }}$ are favorable areas for $S$. aurita eggs and larval coastal retention and survival because of important centers of cyclonic circulation there. These are clearly visible on Fig. 9 where two cells of cyclonic eddies are present and located downstream of the capes, approximately around $4^{\circ} \mathrm{N}$, between the coast and the Guinea Current (Djakouré et al., 2014). These eddies trap eggs and larvae along the coast and they act as physical barrier, preventing their offshore advection and loss (Marchal and Picaut, 1977; Pezennec and Bard, 1992). A strong anticyclonic eddy often occurs near the Niger delta region approximately around $4-6^{\circ} \mathrm{N}$ and $2.5-5^{\circ} \mathrm{W}$, thus trapping larvae in both MEGGin and NEGGin regions. Our simulations suggest that spawning location impacts the subsequent retention of $S$. aurita ichthyoplancton. This result illustrates Iles 
and Sinclair's (1982) hypothesis that the physical retention of early-life stages, is critical in the recruitment process, and is dependent on adult fish spawning in appropriate places where conditions are conducive for retention of eggs and larvae. As expected, the overall values of simulated retention increase with the hot lethal temperature threshold simply because only few individuals die as this threshold increases. For the highest, $28^{\circ} \mathrm{C}$ threshold, very few individuals die, showing that temperatures greater than $28^{\circ} \mathrm{C}$ are not often encountered by individuals. By contrast, there are many individuals dying when the $22^{\circ} \mathrm{C}$ and $25^{\circ} \mathrm{C}$ threshold values are used, indicating that temperatures in the range $22-28^{\circ} \mathrm{C}$ are often encountered by individuals.

The temporal patterns simulated by both SHT22 and SHT25 is in accordance with the study of Krzelj (1972) who pointed out that S. aurita spawns during/or after the cold (upwelling) season with the highest concentration of larvae observed in March and August. Pezennec and Bard (1992), Marchal (1993) and Pezennec (1995) also highlighted that $S$. aurita have two spawning periods occurring during the minor and the major upwelling periods in the Ivorian and Ghanaian upwelling systems. The temporal patterns of simulated retention in both SHT22 and SHT25 mirror the upwelling index derived from the hydrodynamic model in the core of the upwelling cell around Cape Palmas (Fig. 9d). They also match the time evolution of the gonado-somatic index of $S$. aurita caught off Ivory Coast (Fig. 9d; Pezennec and Bard, 1992). These results are strong indications that $S$. aurita spawning is linked to the upwelling seasons. Binet (1982) pointed out that catches of $S$. aurita were correlated to an upwelling index. Supposedly, during the upwelling season, the spawning population gets closer to the coast to reproduce, becoming accessible for fishing, which is essentially operated by small-scale fisheries. The rest of the year, they leave further from the coast in deeper waters and are less accessible to fisheries. Likewise, Cury and Roy (1987) showed that 
the fluctuations of Catch Per Unit of Effort (CPUE) were strongly correlated to an upwelling index. Based on the time evolution of the gonado-somatic index for S. aurita caught off Ivory Coast, Pezennec and Bard (1992) also suggested the existence of two spawning periods for this species occurring during upwelling. According to Quaatey and Maravelias (1999), spawning of $S$. aurita actually begins in response to the start of the coastal upwelling. From historical data collected from 1969 to 1992 by the Marine Fisheries Research Division (MFRD) along a transect off the coast of Ghana, Wiafe et al. (2008) showed that the monthly concentration of $S$. aurita larvae displays two peaks: a moderate one during the minor upwelling and a strong one during the major upwelling. All these findings concur with SHT22 and SHT25 simulations results, but less with SHT28 simulation which failed to reproduce the minor upwelling maximum. Plankton abundance increases during the upwelling period, in particular during the major upwelling period in the Ivoirian and Ghanaian upwelling system (Mensah, 1995; Wiafe et al., 2008), inducing a "match" between the larvae and their food. It is well known that amounts and type of prey are important to support production of larval and pre-recruit fish, as better survival and growth of fish larvae are generally associated with higher prey levels (Riling and Houde 1999; Zenitani et al., 2007; Zeeberg et al., 2008).

Spawning close to the surface leads to high offshore advection of eggs and larvae by the GC which can reach the velocity of $1 \mathrm{~m} \cdot \mathrm{s}^{-1}$ (Richardson and Reverdin, 1987) in the surface layers. The velocity of this current decreases with depth, which involves better condition for coastal retention. As the $28^{\circ} \mathrm{C}$ isotherm is located in the surface layer, most mortality is induced there, which explains why there is little difference between the 25-50 $\mathrm{m}$ and 50-75 $\mathrm{m}$ depth levels in SHT28. Unfortunately, very little information is available on the larval vertical distribution of $S$. aurita in the northern Gulf of Guinea. It is generally assumed that $S$. aurita spawns in the layer between the surface and $50 \mathrm{~m}$ 
depth (Boely and Fréon 1979). According to Mahfoud (2005), S. aurita spawns between the isobaths 30 to $50 \mathrm{~m}$. This is consistent with the distribution of larval Spanish sardine (S. aurita) for the eastern Gulf of Mexico (West coast of Florida) reported by Houde (1973) and Houde et al. (1976). According to these authors, most spawning in the eastern Gulf occurs over wide areas where depths are between 10 and $50 \mathrm{~m}$, although some eggs and larvae have been recovered at $200 \mathrm{~m}$ depth.

Results of a multifactor analysis of variance performed on the retention values for all the simulations confirmed that all single factors (except year) and all 2-way interactions factors (except those including year,) are significant. The importance of the single factors (Area, Month and Depth) is consistent with similar studies performed in the other upwelling systems (Parada et al. 2003; Lett et al. 2007; Brochier et al. 2008). The importance of the first order interaction terms is also consistent with previous studies (Parada et al. 2003; Lett et al. 2007).

\section{CONCLUSIONS}

The hydrodynamic model developed for the northern Gulf of Guinea is able to reproduce a realistic virtual environment that the early stages of $S$. aurita face in our biophysical model. The general patterns of the different environmental variables, including temperature, currents and mixed layer depth, are well reproduced using a climatology forcing data. The physical features are the main processes determining larval drift pathways and retention areas in the biophysical model. We found that two spawning areas are most favorable to larval coastal retention and survival, Cape Palmas $\left(\mathrm{CaP}_{\text {in }}\right)$ and Cape Three Points $\left(\mathrm{CaTP}_{\text {in }}\right)$, when simulations included mortality induced by low temperature $\left(22\right.$ and $\left.25^{\circ} \mathrm{C}\right)$. The cyclonic eddies created on the eastern side of these two capes by the Guinea Current and the anti-cyclonic eddy in the vicinity of the 
Niger delta region act as physical barrier, trapping eggs and larvae along the coast. This result suggests the primacy of such cyclonic and anti-cyclonic eddies in the spatial variability of eggs and larvae abundance. The main features of the early life history of $S$. aurita are summarized in Fig. 12. We also found two most favorable spawning periods during the minor and the major upwelling periods in SHT22 and SHT25, which match the highest biological production in the area of interest.

The study presented here represents an idealized case where food is not limiting. Coupling the hydrodynamic model with a biogeochemical model would provide food availability conditions to the simulated larvae to investigate the respective effects of physical and biological processes on $S$. aurita early life stages in the northern Gulf of Guinea.

\section{Acknowledgements}

We acknowledge funding from the EU FP7/2007-2013 under grant agreement no. 603521, project PREFACE. The authors are also grateful to the AWA project for providing additional data storage capacity. We thank Philippe Verley for his technical support and the contributors to the ggmap and marmap R packages.

\section{Appendix A}

The inter-annual variability of the simulated retention is very weak (Fig. A1). This is not surprising given that a repeated climatology forcing was used in the hydrodynamic model. Therefore inter-annual variability is only due to intrinsic mesoscale activity resulting from oceanic instability processes in the absence of added forced variability. Our result is in agreement with similar studies in the Benguela upwelling system (Mullon et al. 2003; Parada et al. 2003; Lett et al. 2007; Koné et al. 2013) and in the Humbolt Current system (Brochier et al. 2008). 


\section{REFERENCES}

Anderson, J. T. 1988. A Review of Size Dependent Survival During Pre-Recruit Stage of Fishes in Relation to Recruitment. J. Northw. Atl. Sci., 8, 55-66.

Arfi, R., Pezennec, O., Cissoko, S., and Mensah, M., 1991. Variations spatiale et temporelle de la résurgence ivoiro-ghanéenne. In : Cury, P., Roy, C. (ed.) Pêcheries ouest africaines. Variabilité, instabilité et changement. Orstom, Paris, 162-172 p.

Arnault, S., 1987. Tropical Atlantic geostrophic currents and ship drifts. J. of Geophys. Res., 92, C5, 5076-5088.

Bakun, A., 1978. Guinea Current Upwelling. Nature, 271, 147-150.

Berger, H., Treguier, A. M., Perenne, N., and Talandier, C., 2014. Dynamical contribution to sea surface salinity variations in the eastern Gulf of Guinea based on numerical modelling. Climate Dynamics, 43 (11), 3105-3122.

Binet, D., 1982. Influence des variations climatiques sur la pêcherie des S. aurita ivoiroghanéennes : relation sécheresse-surpêche. Oceanologica Acta, 5 (4), 443-452.

Binet, D., 1988. Rôle possible d'une intensification des alizés sur le changement de répartition des sardines et sardinelles le long de la côte ouest africaine. Aquat. Living Resour., 1, 115-132.

Binet, D., 1997. Climate and pelagic fisheries in the Canary and Guinea currents 19641993: the role of trade winds and the southern oscillation. Oceanologica Acta, 20, $1,177-190$. 
Binet, D., and Marchal, E., 1993. The large Marine Ecosystem of Shelf Areas in the Gulf of Guinea: Long-Term Variability Induced by Climatic Changes. In: Large Marin Ecosystems: Storn, Mitigation and Suitainability. Sherman, K., Alexander L. M., Gold, B. D., (eds). AAAS publication 92-395, pp. 104-118.

Binet, D., Marchal, E. and Pezennec, O., 1991. S. aurita de Côte d'Ivoire et du Ghana. Fluctuations halieutiques et changements climatiques. In : Cury, P., Roy, C., (ed) Pêcheries oust-africaines. Variabilité, instabilité et changement. Orstom. Paris. $320-342$.

Boely, T., and Fréon, P., 1979. Les ressources pélagiques côtières. FAO Doc. Tech. Pêches, (186.1): 13-78.

Bourlès, B., Gouriou, Y., and Chuchla, R., 1999. On the circulation in the upper layer of the western equatorial Atlantic. Journal of Geophysical Research, 104, NO C9, $21,151-21,170$.

Brochier, T., Lett, C., Tam, J., Fréon, P., Colas, F., Ayon, P., 2008a. An individual based model study of anchovy early life history in the Humbolt Current system. Progress in Oceanography, 79, 313-325.

Brochier, T., Colas, F., Lett, C., Echevin, V., Cubillos, L. A., Tam, J., Chlaida, M., Mullon, C., and Fréon P., 2009. Small pelagic fish reproductive strategies in upwelling systems: A natal homing evolutionary model to study environmental constraints. Progress in Oceanography, 83, 261-269.

Brochier, T., Mason, E., Moyano, M., Berraho, A., Colas, F., Sangrà, P., HernándezLeón, S., Ettahiri, O., and Lett, C., 2011. Ichthyoplankton transport from the Africa coast to the Canary Islands. Journal of Marine Systems, 87, 109-122. 
Colin, C., 1988. Coastal Upwelling events in front of Ivory Coast during the FOCAL program. Oceanologia Acta, 11, 125-138.

Conand, F., 1977. Oeufs et larves de la Sardinelle ronde (S. aurita) au Sénégal : Distribution, Croissance, Mortalité, Variations d'abondance de 1971 à 1976. Cah. ORSTOMS Sér. Océanogr., 15 :201-214.

Cury, P., and Roy, C., 1987. Upwelling et pêche des espèces pélagiques côtières de Côte d'Ivoire : une approche globale. Oceanologica Acta, 10 (3), 347-357.

Cury, P., Bakun, A., Crawford, R.J.M., Jarre, A., Quiñones, R.A., Shannon, L.J., Verheye, H.M., 2000. Small pelagics in upwelling systems: patterns of interaction and structural changes in "wasp-waist" ecosystems. Ices Journal of Marine Science 57 (3), 603-618.

de Boyer Montégut, C., Madec, G, Fischer, A.S., Lazar, A, and Iudicone, D., (2004), Mixed layer depth over the global ocean: an examination of profile data and a profile-based climatology, J. Geophys. Res., 109, C12003. doi:10.1029/2004JC002378

Da Silva, A., Young C., and Levitus, S., 1994. Atlas of surface marine data 1994:

Algorithms and procedures, vol. 1, technical report, U. S. Dep. of comm., Natl. Oceanic and Atmos. Admin, 74 pp., Silver Spring, Md.

Debreu, L., Mazauric, C., 2006. Adaptative Grid Refinement (AGRIF) in Fortran 90: Users Guide Version 1.3. http://www-lmc.imag.fr/IDOPT/AGRIF/index.htlm.

Debreu, L., Blayo, E., 2008. Two-way embedding algorithms: A review, Ocean Dyn., $58,415-428$. 
Debreu, L., Marchesiello, P., Penven, P., and Cambon, G., 2012. Two-way nesting in split-explicite ocean models: Algorithms, implementation and validation, Ocean Modell., 49-50, 1-21.

Demarcq, H., and Faure, V., 2000. Coastal upwelling and associated retention indices derived from satellite SST. Application to Octopus vulgaris recruitment. Oceanol. Acta, 23 (4): 391-408.

Ditty, J.G., Houde, E.D. and Shaw, R.F., 1994. Egg and larval development of Spanish sardine, Sardinella aurita (Family Clupeidae), with a synopsis of characters to identify clupeid larvae from the Northern Gulf of Mexico. Bull. Mar. Sci., 54:367380.

Djakouré, S., Penven, P., Bourlès, B., Veitch, J., and Koné, V., 2014. Coastally trapped eddies in the north of the Gulf of Guinea. J. Geophys. Res. Oceans, 119, doi: 10.1002/2014JC010243.

Hardman-Mountford, N.J., and McGlade, M., 2003. Seasonal and interannual variability of oceanographic processes in the Gulf of Guinea: An investigation using AVHRR sea surface temperature data. International Journal of Remote Sensing, $24: 16,3247-3268$.

Herbland A., Marchal, E., 1991. Variations locales de l'upwelling, répartition et abondance des sardinelles en Côte d'Ivoire. In : Cury, P., Roy, C., (ed) Pêcheries oust-africaines. Variabilité, instabilité et changement. Orstom. Paris. 343-353.

Hisard, P., Merle, J., 1980. Onset of summer surface cooling in the Gulf of Guinea during GATE. Deep-Sea Research 26 (Suppl. II), 325-341

Houde, E. D., 1973. Estimating abundance of sardine-like fishes from egg and larval surveys, eastern Gulf of Mexico: preliminary report. Proc. Gulf Caribb. Fish. Inst. 25: 68-78. 
Houde, E. D., Berkeley, S. A., Klinovsky, J. J., and Dowd, C. E., 1976. Ichthyoplankton survey data report. Univ. of Miami Sea Grant Program, Sea Grant Tech. Bull. 32, $193 \mathrm{p}$.

Houde, E. D., 2008. Emerging from Hjort's Shadow. J. Northw. Atl. Fish. Sci., 41:5370, doi:10.2960/J.v41.m634.

Iles, T. D. and Sinclair M., 1982. Atlantic herring: stock discreteness and abundance. Science, 215: 627-633. Doi:10.1126/science.212.4533.627.

Jacobson, L.D., De Oliveira, J.A.A., Barange, M., Cisneros-Mata, M.A., Félix-Uraga, R., Hunter, J.R., Kim, J.Y., Matsuura, Y., Ñiquen, M., Porteiro, C., Rothschild, B., Sanchez, R.P., Serra, R., Uriarte, A., Wada, T., 2001. Surplus production, variability, and climate change in the great sardine and anchovy fisheries. Canadian Journal of Fisheries and Aquatic Sciences 58 (9), 1891-1903.

Kara, A.B., Rochford, P.A., and Hurlburt, H.E., 2003. Mixed layer depth variability over the global ocean. J. Geophys. Res., 108(C3), 3079, doi:10.1029/2000JC000736.

Koné, V., Lett, C., and Fréon, P., 2013. Modelling the effect of food availability on recruitment success of Cape anchovy ichthyoplankton in the southern Benguela upwelling system. African Journal of Marine Science, 35 (2): 151-161.

Krzelj, S., 1972. Etude de la distribution et de l'abondance des larves de clupéidés sur le plateau continental ivoirien. Projet de développement de la pêche pélagique côtière durant la période 1971-72. FAO/PNUD IVC 6/288, Abidjan, RS 6/72, 15p.

Leggett, W. C., and Deblois, E., 1994. Recruitment in marine fishes: is it regulated by starvation and predation in the egg and larval stages? Netherlands Journal of Sea Research, 32 (2), 119-134. 
Lett, C., Veitch, J., van der Lingen, C. D., and Hutchings L., 2007a. Assessment of an environmental barrier to transport of ichthyoplankton from the southern to the northern Benguela ecosystems, 347: 247-259. doi: 10.3354/meps06982.

Lett, C., Penven, P., Ayón, P., and Fréon, P., 2007b. Enrichment, concentration and retention processes in relation to anchovy (Engraulis ringens) eggs and larvae distributions in the northern Humboldt upwelling ecosystem. Journal of Marine Systems, 64, 189-200.

Lett, C., Verley, P., Mullon C., Parada, C., Brochier, T., Penven, P., Blanke, B., 2008. A lagrangian tool for modelling ichthyoplankton dynamics. Environmental Modelling and Software 23: 1210-1214.

Lorbacher, K., Dommenget, D., Niiler, P.P., and Köhl, A., 2006. Ocean mixed layer depth: A subsurface proxy of ocean-atmosphere variability. Journal of Geophysical Research, 111, C07010, doi:10.1029/2003JC002157.

Lumpkin, R., and Garraffo, Z., 2005. "Evaluating the Decomposition of Tropical Atlantic Drifter Observations". J. Atmos. Ocean. Tech., 22: 1403-1415.

Lumpkin, R., and Johnson, G., 2013. Global Ocean surface velocities from drifters: Mean, variance, El Niño-Southern Oscillation response and seasonal cycle. J. Geophys. Res. Oceans, 118, 2992-3006, doi: 10.1002/jgrc.20210.

Mahfoudh, M. O. T. O. S., 2005. Les ressources de petits pélagiques en Mauritanie et dans la zone nord-ouest africaine : variabilité spatiale et temporelle, dynamique et diagnostic. $\mathrm{PhD}$ thesis, Ecole Normale Supérieure Agronomique de Rennes, Rennes, France, p. 44.

Marchal, E., 1991. Un essai de caractérisation des populations de poissons pélagiques côtiers : cas de S. aurita des côtes ouest-africaines. In Pêcheries ouest-africaines. 
Variabilité, instabilité et changement. Cury, P., Roy, C. (eds), Orstom, Paris, 192200.

Marchal, E., 1993. Biologie et Ecologie des poisons pélagiques côtiers du littoral ivoirien. In : Le milieu marin. Environnement et ressources aquatiques de Côte d'Ivoire. Le Loeuf, P., Marchal, E., and Amon Kothias, J.-B. (eds), Orstom, Paris, 237-269 p.

Marchal, E., and Picaut, J., 1977. Répartition et abondance évaluées par échointégration des poissons du plateau ivoiro-ghanéen en relation avec les upwellings locaux. J. Rech. Océanogr., 2 (4), 39-58.

Marin, F., Caniaux, G., Bourlès, B., Giordani, H., Gouriou, Y., and Key, E., 2009. Why Were Sea Surface Temperatures so Different in the Eastern Equatorial Atlantic in June 2005 and 2006? Journal of Physical Oceanography, 39, doi:10.1175/2008JPO4030.1

M'Baye, B. C., Brochier, T., Echevin, V., Lazar, A., Lévy, M., Mason, E., Gaye, A. T., and Machu, E., 2015. Do S. aurita spawning seasons match local retention patterns in the Senegalese-Maritanian upwelling region? Fish. Oceanogr., 24:1, 69-89.

Mensah, M. A., 1995. The occurrence of zooplankton off tema during the period 19691992. In Dynamics and Use of S. Ressources from upwelling off Ghana and Ivory Coast. Bard, F.-X., and Koranteng, K. A. (eds), ORSTOM, Paris, pp. 279-289.

Mullon, C., Fréon, P., Parada, P., van der Lingen, C., Huggett, J., 2003. From particles to individuals: modeling the early stages of anchovy in the southern Benguela. Fishery Oceanography 12: 396-406.

Parada, C., Mullon, C., Roy, C., Fréon, P., Hutchings L., van der Lingen, C. D., 2008. Does vertical migratory behavior retain fish larvae onshore in upwelling 
ecosystems? A modeling study of anchovy in the southern Benguela. African Journal of Marine Science, 30: 437-452.

Parada, C., van der Lingen, C., Mullon, C., Penven P., 2003. The effect of buoyancy on the transport of anchovy (Engraulis capensis) eggs from spawning to nursery grounds in the Southern Benguela: an IBM approach. Fishery Oceanography, 12: $1-15$.

Peliz, A., Marchesiello, P., Dubert, J., Marta-Almeida, M., Roy, C., Queiroga, H., 2007. A study of crab larvae dispersal on the western Iberian shelf: physical processes. Journal of Marine Systems, doi: 10.1016/j.jmarsys.2006.11.007.

Penven, P., Marchesiello, P., Debreu, L., and Lefèvre, J., 2008. Software tools for preand post-processing of oceanic regional simulations. Environ. Modell. Software, $23,660-662$.

Pezennec, O., and Bard, F.-X., 1992. Importance écologique de la petite saison d'upwelling ivoiro-ghanéenne et changements dans la pêcherie de Sardinelle aurita. Aquat. Living Resour., 5, 249-259.

Pezennec, O., 1994. Instabilité et changements de l'écosystème pélagique côtier ivoiroghanéen. Variabilité de la ressource en sardinelles : faits, hypothèses et théories. PhD thesis, Université de Bretagne Occidentale, Brest, France.

Pezennec, O., 1995. Ecological importance of the Ivorian and Ghanaian minor upwelling season. In Bard, F.-.X (ed), Korenteng, K.A. (ed). Dynamics and used of S. resources from upwelling off Ghana and Ivory Coast: acts of DUSRU meeting. Paris, ORSTOM, p. 324-345.

Quaatey, S. N. K., and Maravelias, C. D., 1999. Maturity and spawning pattern of $S$. aurita in relation to water temperature and zooplankton abundance off Ghana, West Africa. Journal of Applied Ichthyology, 15: 63-69. 
Reynolds, R. W., T. M. Smith, C. Liu, D. B. Chelton, K. S. Casey, and M. G. Schlax, 2007: Daily high-resolution blended analyses for sea surface temperature. J. Climate, 20, 5473-5496.

Richardson, P.L., and Philander, S.G.H., 1987. The seasonal variations of surface currents in the tropical Atlantic Ocean: A comparison of ship drift data with results from a general circulation model. Journal of Geophysical Research, 92, 715-724.

Richardson, P.L., and Reverdin, G., 1987. Seasonal cycle of velocity in the Atlantic North Equatorial Countercurrent as measured by surface drifters, current meters, and ship drifts. Journal of Geophysical Research, 92, 3691-3708.

Rilling, G. C., and Houde, E. D., 1999. Regional and temporal variability in growth and mortality of bay anchovy, Anchoa mitchilli, larvae in Chesapeake Bay. Fish. Bull., 97: 555-569.

Risien, C. M., and Chelton, D. B., 2008. A global climatology of surface wind and wind stress fields from eight years of quikscat scatterometer data. J. Phys. Oceanogr., $38,2379-2413$.

Roy, C., Cury, P., Fontana, A., and Belvèze, H., 1989. Stratégies spatio-temporelles de la reproduction des clupéidés des zones d'upwelling d'Afrique de l'Ouest. Aquat. Living Resour., 2, 21-29.

Schott, F. A., Fisher, J., and Stramma, L., 1998. Transport and pathways of the upperlayer circulation in the western tropical Atlantic. J. Phys. Oceanogr., 28 (10), 1904-1928.

Schott, F. A., McCreary, J. P. Jr., and Johnson, G. C., 2004. Shallow Overturning Circulations of the Tropical-Subtropical Oceans. In Earth Climate: The Ocean- 
Atmosphere Interaction, Geophysical Monograph Series 147, doi:

10.1029/147GM15.

Shchepetkin, A. F., and McWilliams J. C., 2005. The Regional Ocean Model System (ROMS): A split-explicit, free-surface, topography-following-coordinate oceanic model. Ocean Modell., 9, 347-404.

Stramma, L., and Schott, F., 1999. The mean flow field of the tropical Atlantic Ocean. Deep Sea Res., Part II, 46, 279-303.

Tacon, A.G.J., Metian, M., 2009. Fishing for feed or fishing for food: increasing global competition for small pelagic forage fish. Ambio 38, 294-302.

Veitch, J., Penven P., Shillington F., 2009. The Benguela: A laboratory for comparative modeling studies. Progress in Oceanography, 83(1-4), 296-302.

Verstraete, J-M., 1992. The seasonal upwellings in the Gulf of Guinea. Prog. Oceanog., 29, 1-60.

Wahl, S., Latif M., Keenlyside N., 2009. On the Tropical Atlantic SST warm bias in the Kiel Climate model. Clim. Dyn., doi 10.1007/s00382-009-0690-9

Wiafe, G., Yaqub, H. B., Mensah, M. A., and Frid, C. L. J., 2008. Impact of climate change on long-term zooplankton biomass in the upwelling region of the Gulf of Guinea. ICES Journal of Marine Science, 65: 318-324.

Zeeberg, J., Corten, A., Tjoe-Awie, P., Coca, J. and Hamady, B., 2008. Climate modulates the effects of $S$. aurita fisheries off Northwest Africa. Fisheries Research, 89, 65-75.

Zenitani, H., KONO, N., and Tsukamoto, Y., 2007. Relationship between daily survival rates of larval Japanese anchovy (Engraulis Japanicus) and concentrations of copepod nauplii in the Seto Inland Sea, Japan. Fish. Oceanogr., 16: 473-478. Doi: 10.1111/j.1365-2419.2007.00434.X 


\section{Figures captions}

Figure 1: The horizontal grid of the hydrodynamic model. Resolution is $\sim 22 \mathrm{~km}$ for parent domain, and $\sim 7 \mathrm{~km}$ for child domain.

Figure 2: S. aurita spawning and recruitment areas defined in the biophysical model. The numbers 1 to 6 are assigned to: Cape Palmas inshore $\left(\mathrm{CaP}_{\text {in }}\right)$, Cape Palmas offshore $\left(\mathrm{CaP}_{\text {off }}\right)$, Cape Three Points inshore $\left(\mathrm{CaTP}_{\text {in }}\right)$, Cape Three Points offshore $\left(\mathrm{CaTP}_{\text {off }}\right)$, Mid-East Gulf of Guinea inshore $\left(\mathrm{MEGG}_{\mathrm{in}}\right)$ and North-East Gulf of Guinea inshore $\left(\mathrm{NEGG}_{\mathrm{in}}\right)$, respectively.

Figure 3: Seasonal distribution of sea surface temperature (SST) over the child domain for the model (upper panels) and the WOA product (lower panels). The contour interval is $0.25^{\circ} \mathrm{C}$. The SSTs were averaged over the period January-March for the warm season (boreal winter, left panels), and over July-September for the cold season (boreal summer, right panels).

Figure 4: Time evolution of SST averaged over the different onshore spawning areas : a) $\mathrm{NEGG}_{\text {in }}$, b) $\mathrm{CaTP}_{\text {in }}$, c) $\mathrm{CaP}_{\text {in }}$.

Figure 5: Mean seasonal zonal velocities $\left(\mathrm{m}_{\mathrm{s}} \mathrm{s}^{-1}\right)$ in boreal winter (left panels) and summer (right panels), derived from: (a, b) the model and (c, d) NOAA's drifters data.

Figure 6: Mean seasonal distribution of the mixed layer depth in boreal winter (left panels) and summer (right panels), derived from: (a, b) the ROMS model and (c, d) data of de Boyer Montégut et al., (2004). 
Figure 7: Typical example of larval dispersal patterns simulated by the biophysical model from the time of release to the end of the tracking period (28 days). The maps were obtained for particles released the $1^{\text {st }}$ July of the model year 8 in the subsurface layer (25-50 m) for SHT28 simulation. The color bar represents the number of drifters (each color represents one drifter).

Figure 8: Mean (and standard error) percentage of simulated retention obtained in the biophysical model for the different spawning areas (see Fig. 2 for abbreviations).

Figure 9: Seasonal variability of drift patterns simulated by the biophysical model. The white arrows emphasize the cyclonic and anti-cyclonic eddies. The maps were obtained for particles released the $1^{\text {st }}$ of each month of the model year 8 in the subsurface layer 25-50 m for SHT28 simulation.

Figure 10: $(\mathrm{a}, \mathrm{b}$, and $\mathrm{c}$ ) Mean (and standard error) percentage of simulated retention obtained in the biophysical model for the different spawning months. (d) Time evolution of a coastal upwelling index derived from the ROMS model using the methodology of Demarcq and Faure, (2000), averaged in the core of the upwelling cell around Cape Palmas between $7^{\circ} \mathrm{W}$ to $5.7^{\circ} \mathrm{W}$. On the same plot, the gonadosomatic index of S. aurita caught off Ivory Coast from 1989-1991 is shown.

Figure 11: Mean (and standard error) percentage of simulated retention for different spawning depth levels.

Figure 12: A conceptual model of the early life history of $S$. aurita in the northern Gulf of Guinea. 
Figure A1: Mean (and standard error) percentage of simulated retention for different spawning years. 


\section{Tables captions}

Table 1: Results of a multifactor ANOVA performed for a linear model with 2-way interaction fitted on simulated retention values from SHT22. $\mathrm{df}=$ degrees of freedom, $\mathrm{SS}=$ Sum of squares, $\mathrm{MS}=$ Mean Square, $\mathrm{P}=$ Probability, Var $=$ Variance, $* * * \mathrm{P}<$ $0.001, * * \mathrm{P}<0.01, \mathrm{~ns}$ : not significant.

Table 2: Same as Table 1 but for SHT25.

Table 3: Same as Table 1 but for SHT28.

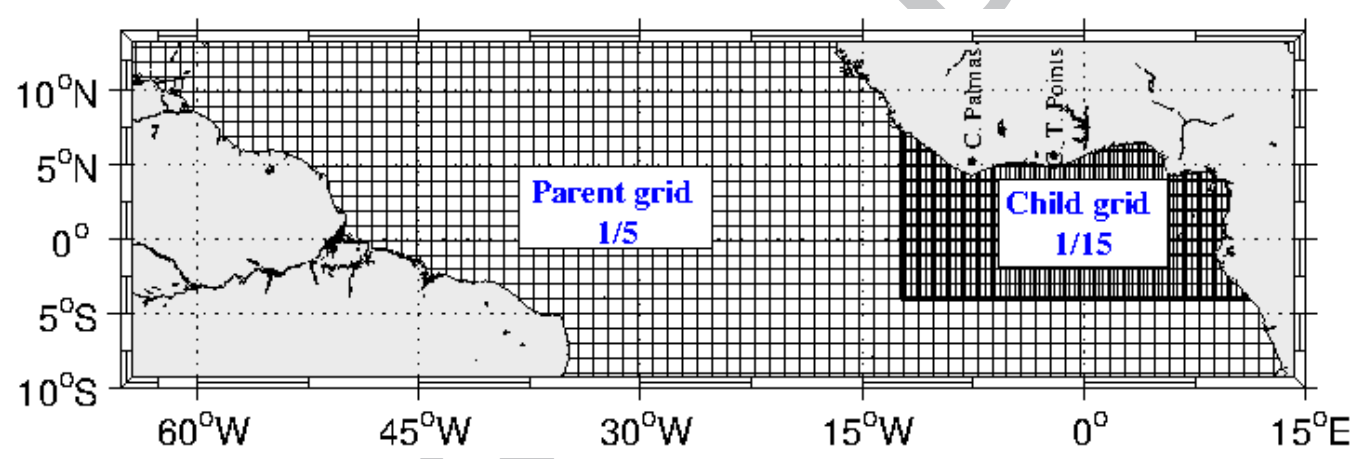

Figure 1: The horizontal grid of the hydrodynamic model. Resolution is $\sim 22 \mathrm{~km}$ for parent domain, and $\sim 7 \mathrm{~km}$ for child domain. 


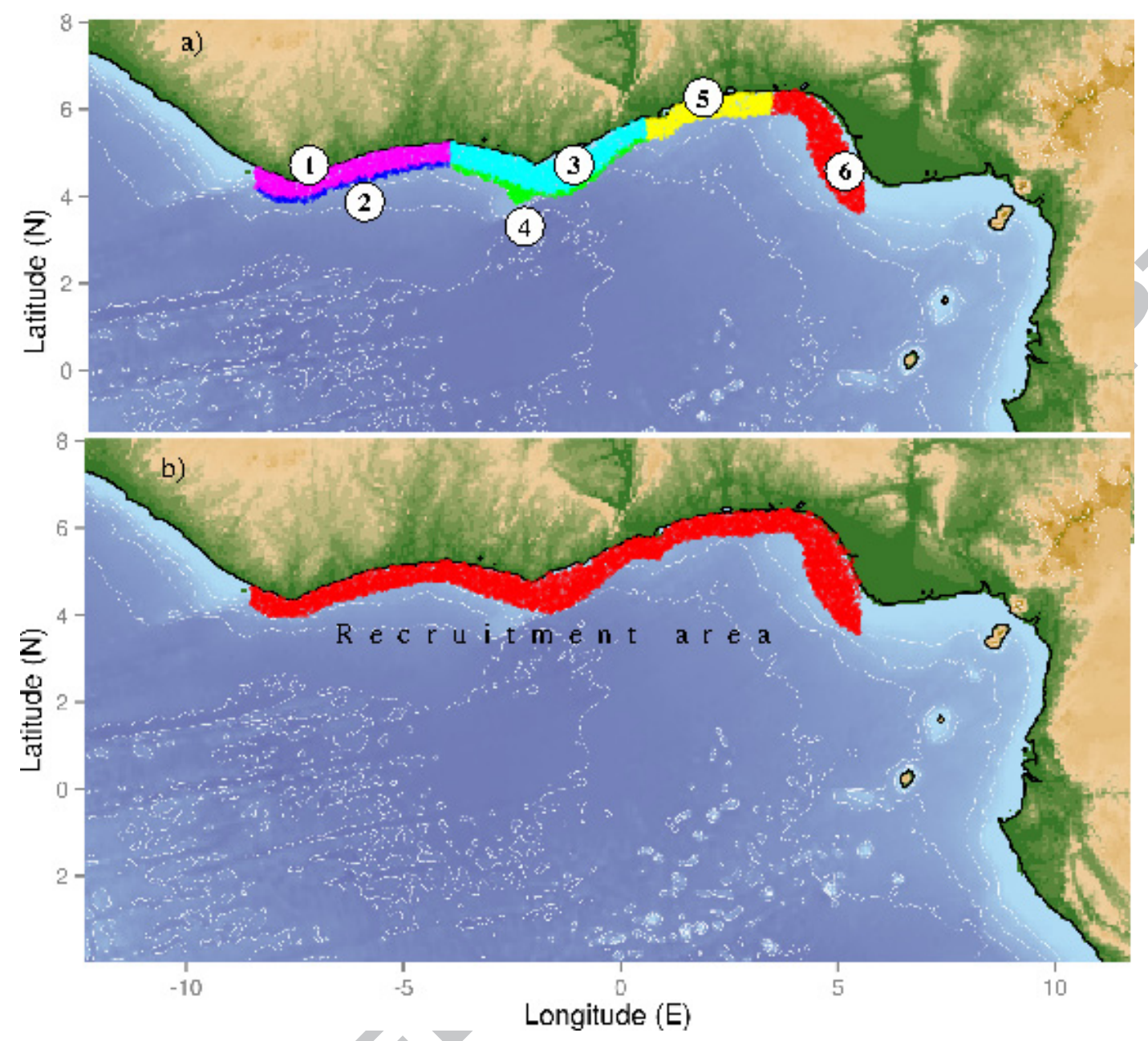

Figure 2: S. aurita spawning and recruitment areas defined in the biophysical model.

The numbers 1 to 6 are assigned to: Cape Palmas inshore $\left(\mathrm{CaP}_{\text {in }}\right)$, Cape Palmas offshore $\left(\mathrm{CaP}_{\text {off }}\right)$, Cape Three Points inshore $\left(\mathrm{CaTP}_{\text {in }}\right)$, Cape Three Points offshore $\left(\mathrm{CaTP}_{\text {off }}\right)$, Mid-East Gulf of Guinea inshore $\left(\mathrm{MEGG}_{\mathrm{in}}\right)$ and North-East Gulf of Guinea inshore $\left(\mathrm{NEGG}_{\mathrm{in}}\right)$, respectively. 

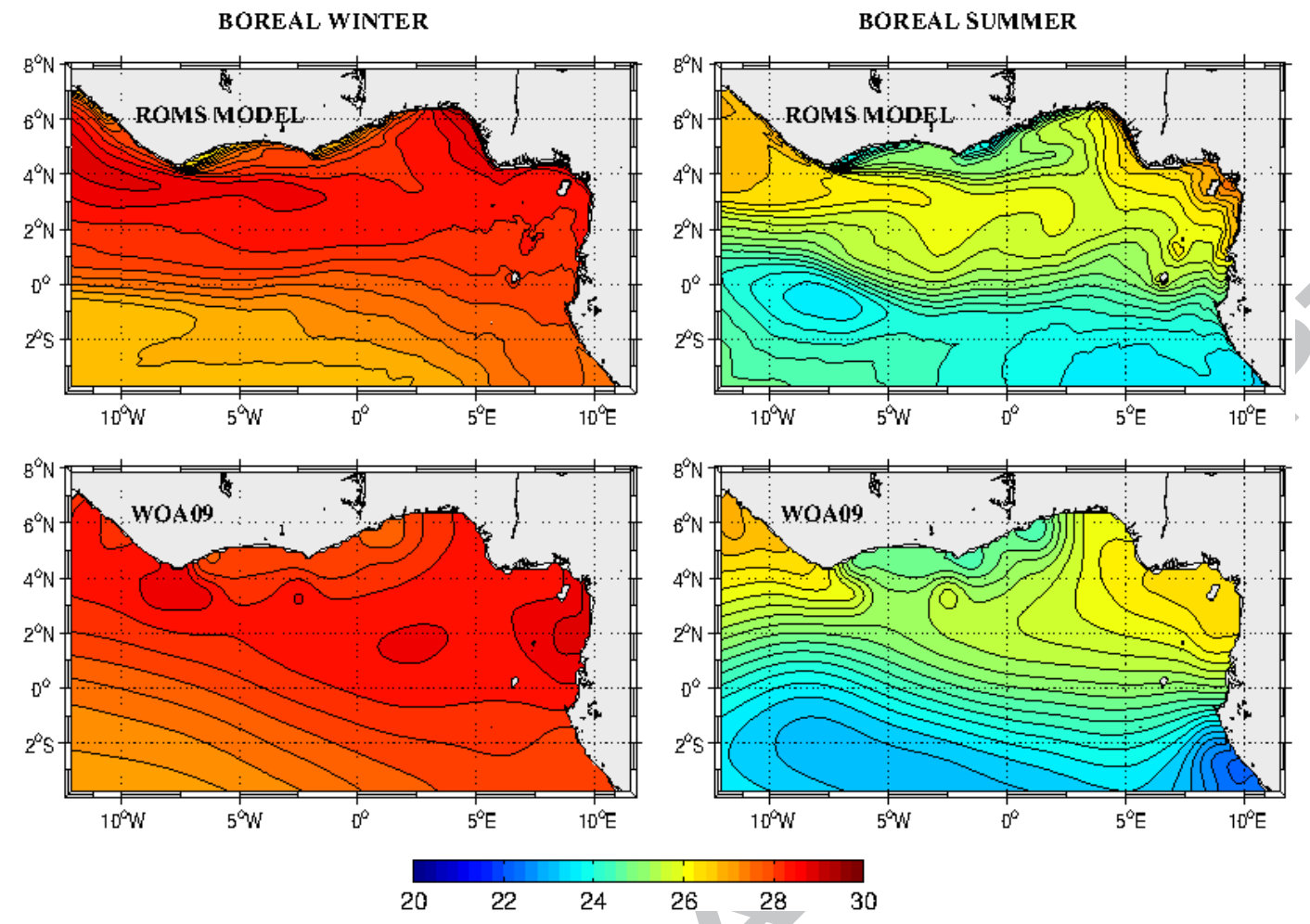

Figure 3: Seasonal distribution of sea surface temperature (SST) over the child domain for the model (upper panels) and the WOA product (lower panels). The contour interval is $0.25^{\circ} \mathrm{C}$. The SSTs were averaged over the period January-March for the warm season (boreal winter, left panels), and over July-September for the cold season (boreal summer, right panels). 


\section{ACCEPTED MANUSCRIPT}

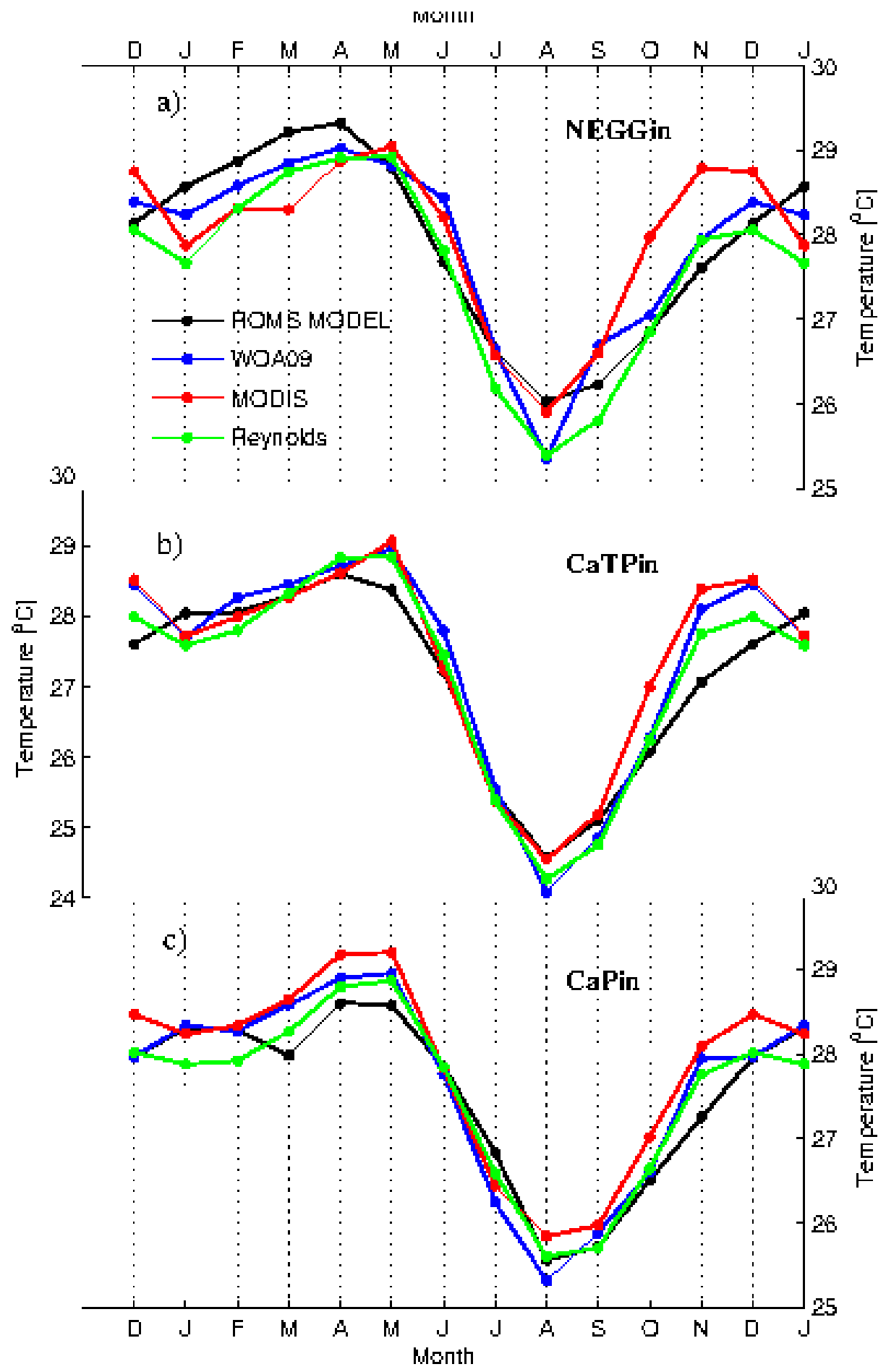

Figure 4: Time evolution of SST averaged over the different onshore spawning areas: a)

$$
\mathrm{NEGG}_{\text {in }}, \text { b) } \mathrm{CaTP}_{\text {in }}, \text { c) } \mathrm{CaP}_{\text {in }} \text {. }
$$



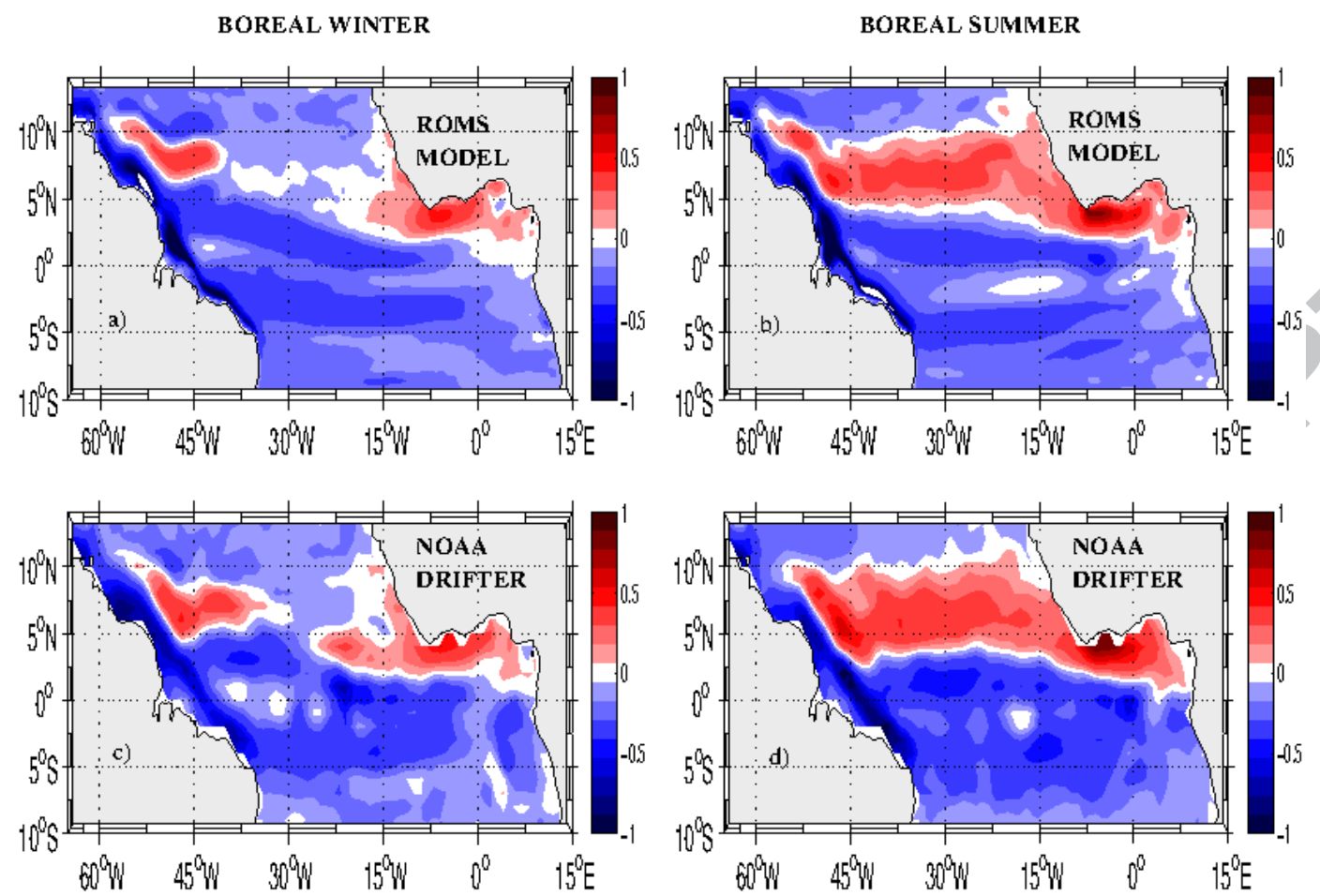

Figure 5: Mean seasonal zonal velocities $\left(\mathrm{m} . \mathrm{s}^{-1}\right)$ in boreal winter (left panels) and summer (right panels), derived from: (a, b) the model and (c, d) NOAA's drifters data. 
BOREAL WINTER
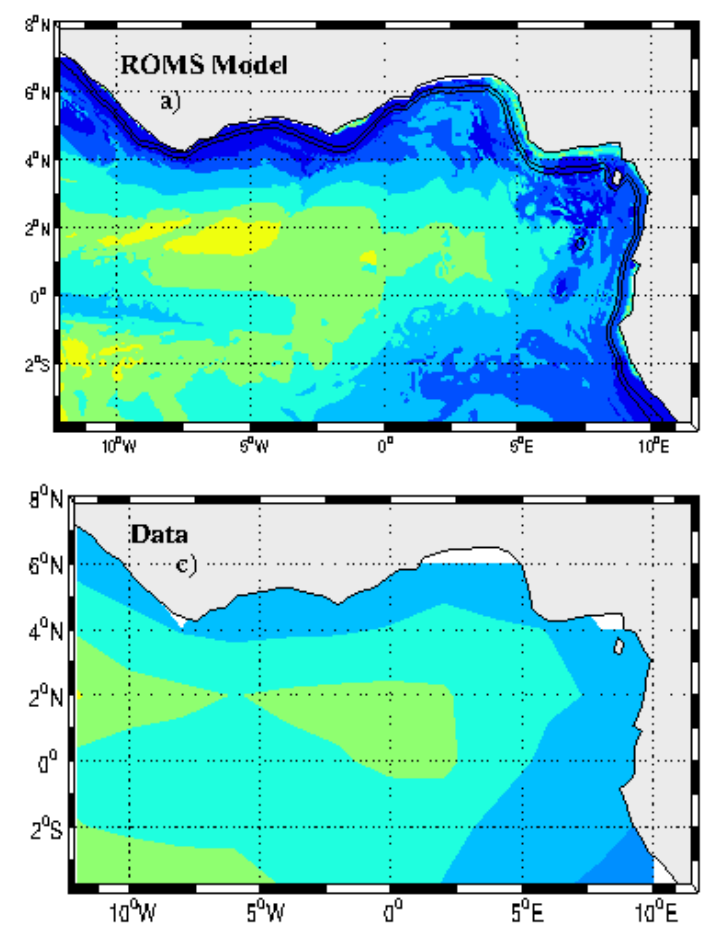

BOREAL SUMMER
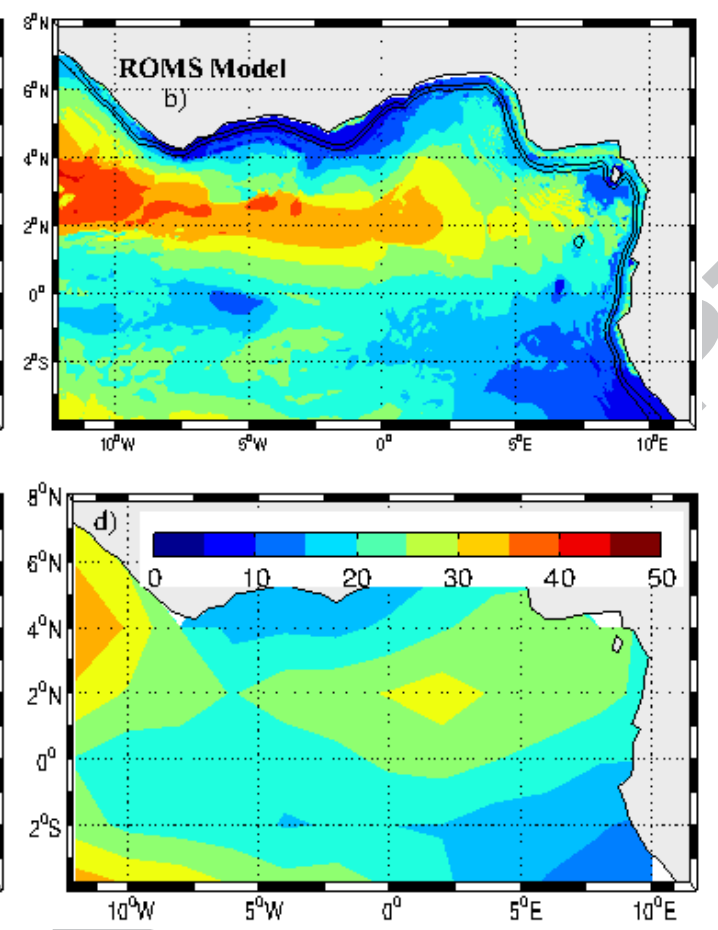

Figure 6: Mean seasonal distribution of the mixed layer depth in boreal winter (left panels) and summer (right panels), derived from: (a, b) the ROMS model and (c, d) data of de Boyer Montégut et al., (2004). 

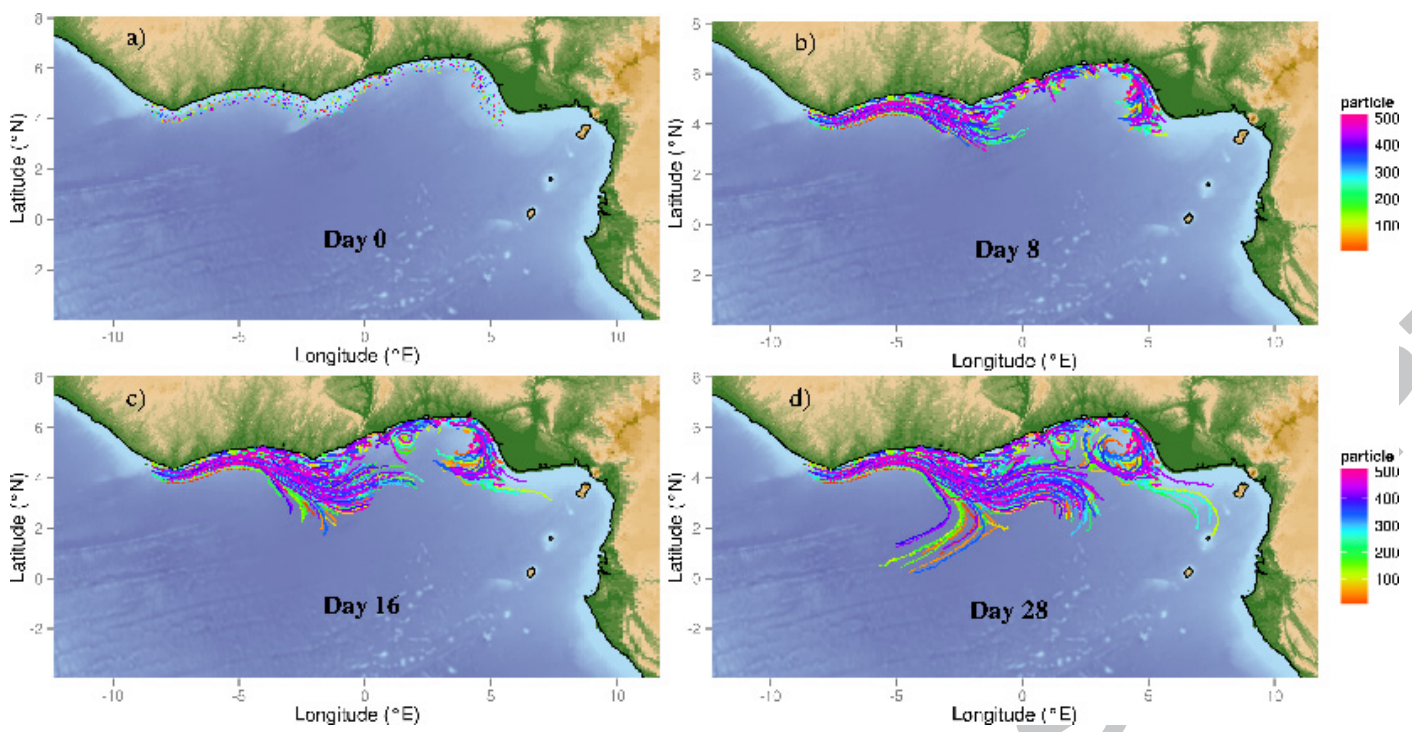

Figure 7: Typical example of larval dispersal patterns simulated by the biophysical model from the time of release to the end of the tracking period (28 days). The maps were obtained for particles released the $1^{\text {st }}$ July of the model year 8 in the subsurface layer (25-50 m) for SHT28 simulation. The color bar represents the number of drifters (each color represents one drifter). 

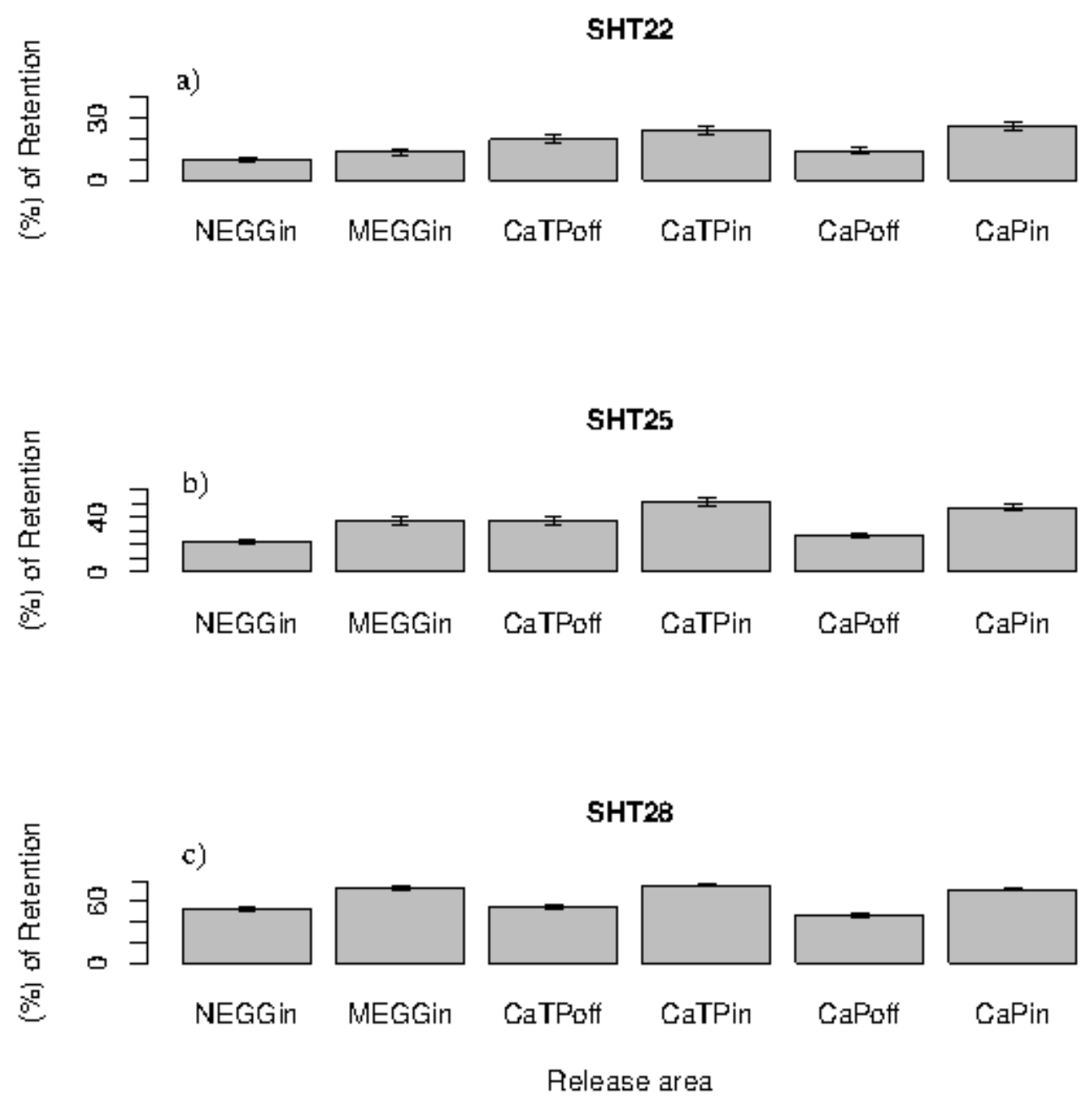

Figure 8: Mean (and standard error) percentage of simulated retention obtained in the biophysical model for the different spawning areas (see Fig. 2 for abbreviations). 

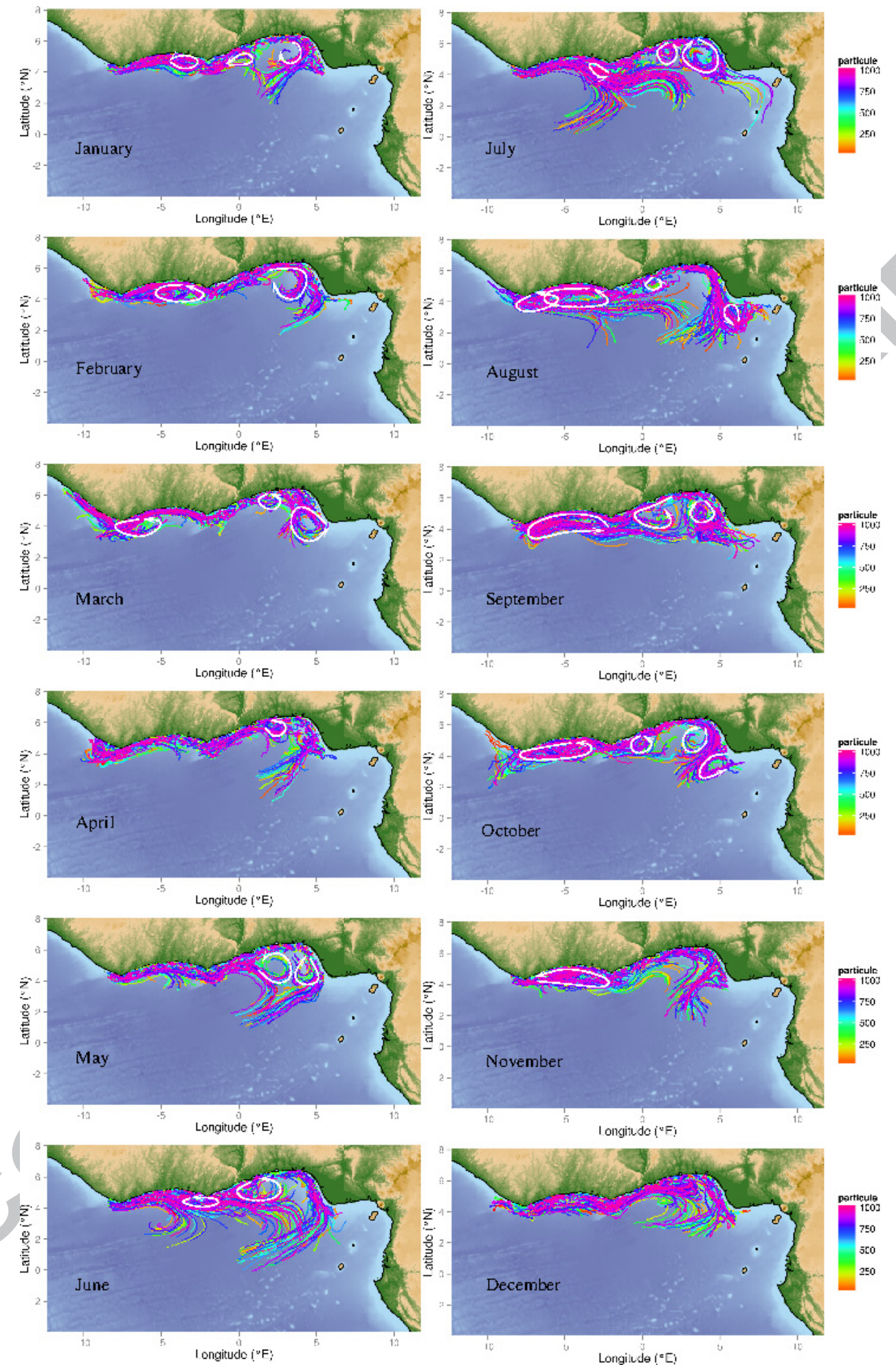

Figure 9: Seasonal variability of drift patterns simulated by the biophysical model. The

white arrows emphasize the cyclonic and anti-cyclonic eddies. The maps were 
obtained for particles released the $1^{\text {st }}$ of each month of the model year 8 in the subsurface layer 25-50 m for SHT28 simulation. 

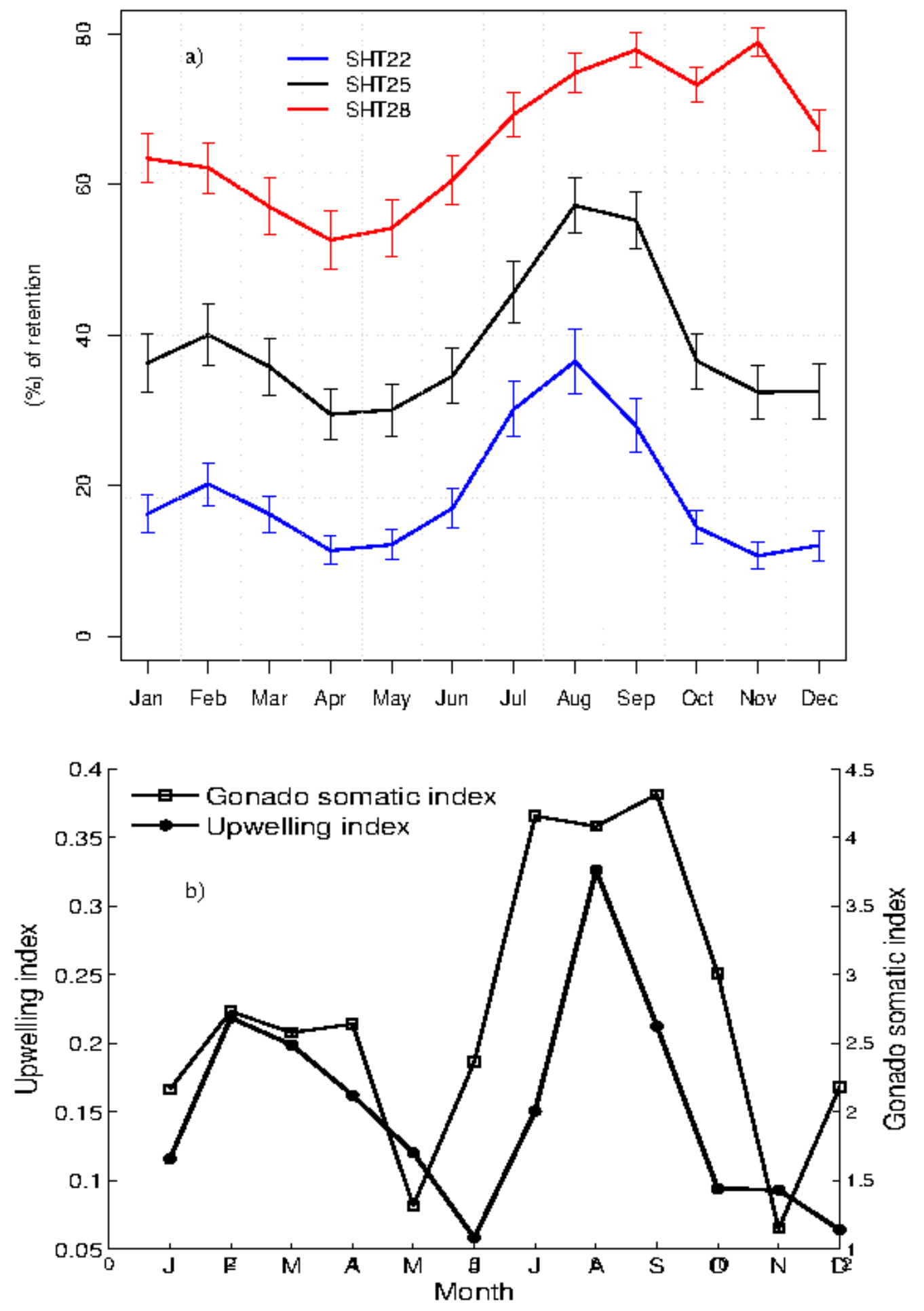

Figure 10: $(a, b$, and c) Mean (and standard error) percentage of simulated retention obtained in the biophysical model for the different spawning months. (d) Time 
evolution of a coastal upwelling index derived from the ROMS model using the methodology of Demarcq and Faure, (2000), averaged in the core of the upwelling cell around Cape Palmas between $7^{\circ} \mathrm{W}$ to $5.7^{\circ} \mathrm{W}$. On the same plot, the gonadosomatic index of S. aurita caught off Ivory Coast from 1989-1991 is shown. 
SHT22

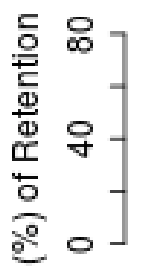

a)
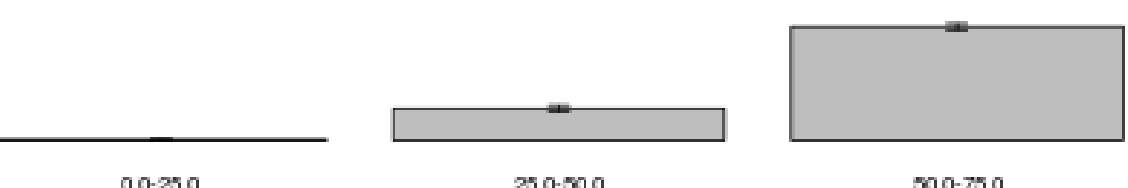

$50.0-75.0$

SHT25

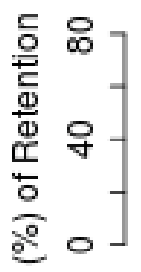

b)

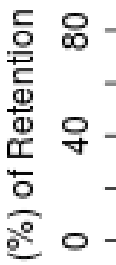

c)

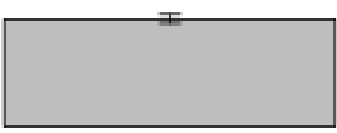

25.0-50.0

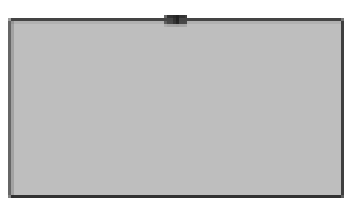

$50.0-75.0$

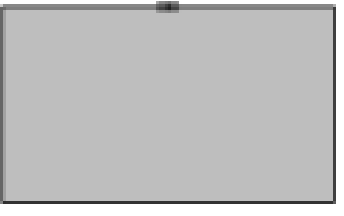

$50.0-75.0$

Release depth (m)

Figure 11: Mean (and standard error) percentage of simulated retention for different spawning depth levels. 


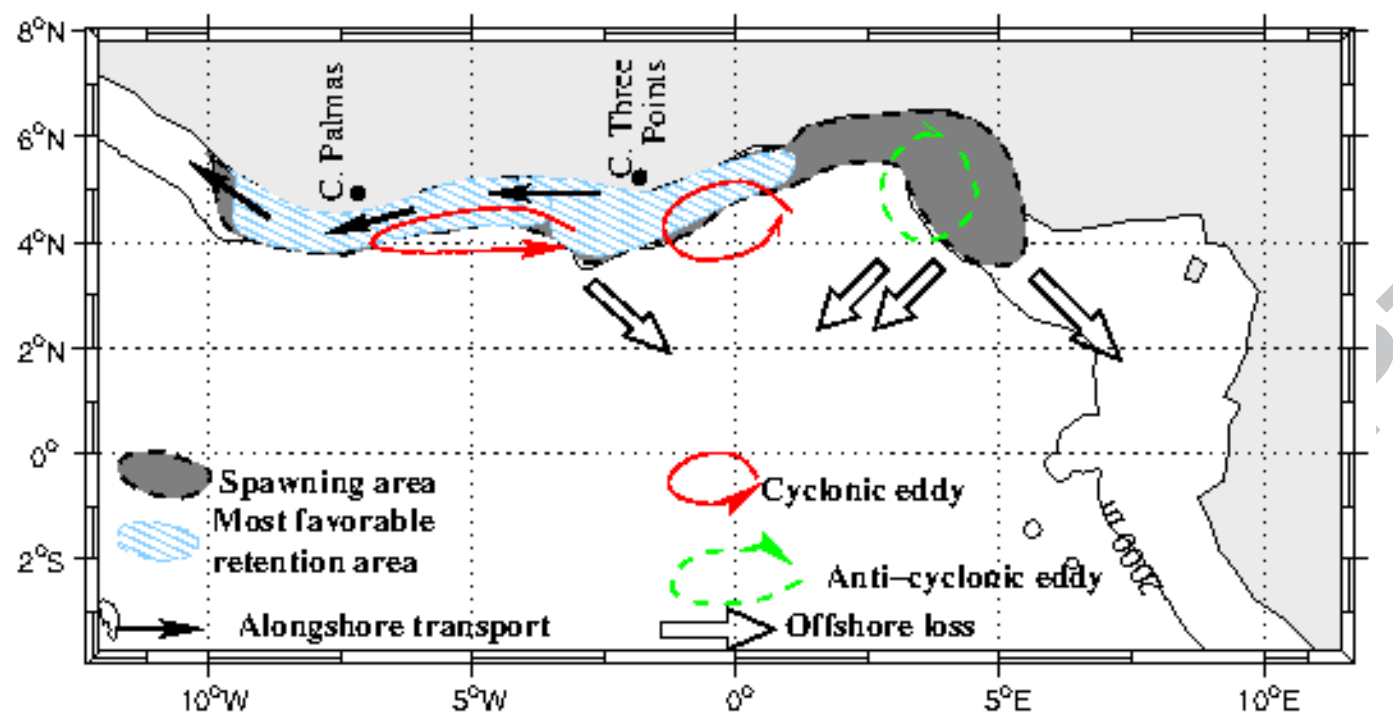

Figure 12: A conceptual model of the early life history of S. aurita in the northern Gulf of Guinea. 


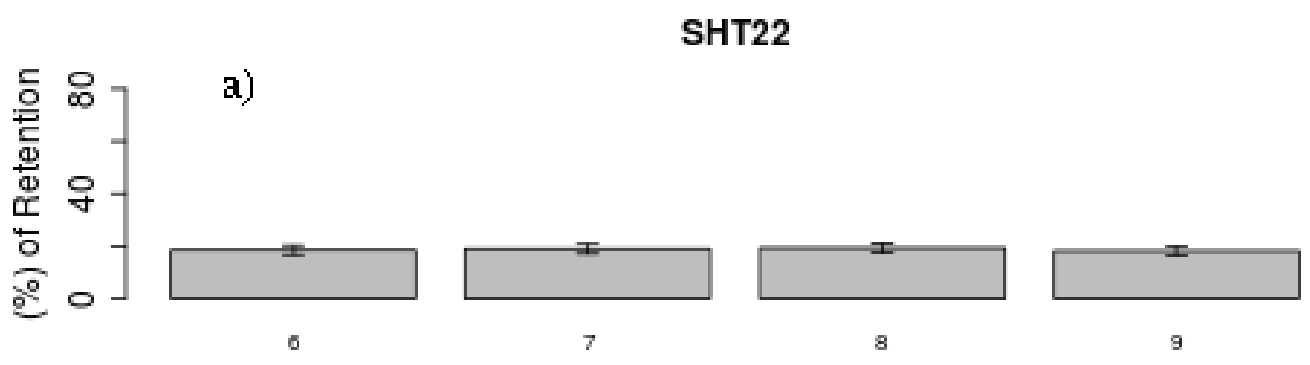

SHT25

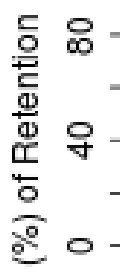

b)
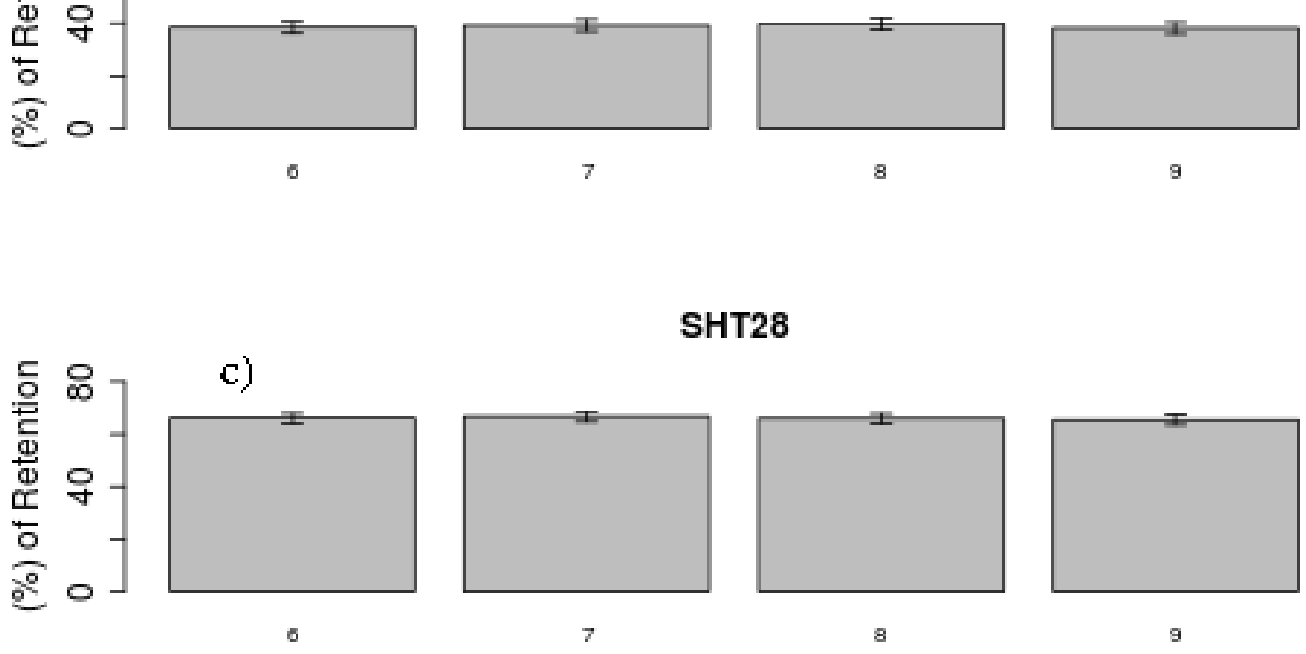

SHT28
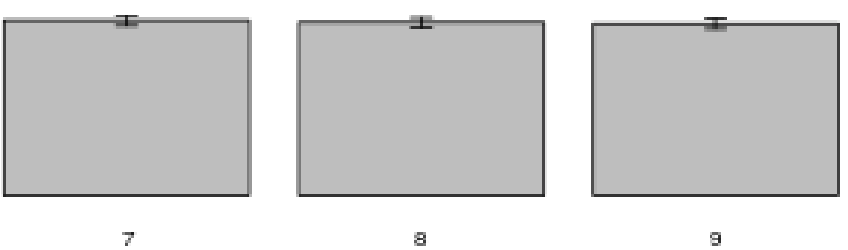

Release year

Figure A1: Mean (and standard error) percentage of simulated retention for different spawning years. 
Table 1: Results of a multifactor ANOVA performed for a linear model with 2-way interaction fitted on simulated retention data derived from SHT22. $\mathrm{df}=$ degrees of freedom, $\mathrm{SS}=$ Sum of squares, $\mathrm{MS}=$ Mean Square, $\mathrm{P}=$ Probability, Var = Variance, $* * * \mathrm{P}<0.001, \mathrm{~ns}$ : not significant.

\begin{tabular}{|c|c|c|c|c|c|c|}
\hline Factor & Df & SS & MS & F-value & $\mathrm{P}$ & $\% \operatorname{Var}$ \\
\hline Area & 5 & 29173 & 5835 & 148.0048 & $* * *$ & 6.78 \\
\hline Month & 11 & 45987 & 4181 & 106.0503 & $* * *$ & 10.68 \\
\hline Year & 3 & 198 & 66 & 1.6781 & ns & 0.05 \\
\hline Depth & 2 & 259481 & 129740 & 3291.0986 & $* * *$ & 60.27 \\
\hline Area $x$ Month & 55 & 26541 & 483 & 12.2411 & $* * *$ & 6.16 \\
\hline Area x Year & 15 & 840 & 56 & 1.4210 & $* * *$ & 0.19 \\
\hline Area $x$ Depth & 10 & 13912 & 1391 & 35.2898 & $* * *$ & 3.23 \\
\hline Month x Year & 33 & 1768 & 54 & 1.3593 & ns & 0.41 \\
\hline Month x Depth & 22 & 24749 & 1125 & 28.5368 & $* * *$ & 5.75 \\
\hline Year x Depth & 6 & 213 & 36 & 0.9009 & ns & 0.05 \\
\hline Residuals & 701 & 27635 & 39 & & & 6.41 \\
\hline
\end{tabular}


Table 2: Same as Table 1 but for SHT25.

\begin{tabular}{|c|c|c|c|c|c|c|}
\hline Factor & Df & SS & MS & F-value & $\mathrm{P}$ & $\% \operatorname{Var}$ \\
\hline Area & 5 & 88152 & 17630 & 237.2688 & $* * *$ & 11.5 \\
\hline Month & 11 & 63270 & 5752 & 77.4081 & $* * *$ & 8.25 \\
\hline Year & 3 & 367 & 122 & 1.6459 & ns & 0.05 \\
\hline Depth & 2 & 454082 & 227041 & 3055.5019 & $* * *$ & 59.24 \\
\hline Area x Month & 55 & 41909 & 762 & 10.2548 & $* * *$ & 5.46 \\
\hline Area x Year & 15 & 2419 & 161 & 2.17 & $* *$ & 0.32 \\
\hline Area x Depth & 10 & 30789 & 3079 & 41.4351 & $* * *$ & 4.02 \\
\hline Month x Year & 33 & 3639 & 110 & 1.4842 & ns & 0.47 \\
\hline Month x Depth & 22 & 29243 & 1329 & 17.8886 & $* * *$ & 3.81 \\
\hline Year x Depth & 6 & 489 & 81 & 1.0958 & ns & 0.06 \\
\hline Residuals & 701 & 52088 & 74 & & & 6.79 \\
\hline
\end{tabular}


Table 3: Same as Table B1 but for SHT28.

\begin{tabular}{|c|c|c|c|c|c|c|}
\hline Factor & Df & SS & MS & F-value & $\mathrm{P}$ & $\%$ Var \\
\hline Area & 5 & 117537 & 23507 & 219.8391 & $* * *$ & 20.16 \\
\hline Month & 11 & 63705 & 5791 & 54.1605 & $* * *$ & 10.92 \\
\hline Year & 3 & 145 & 48 & 0.4534 & ns & 0.02 \\
\hline Depth & 2 & 109490 & 54745 & 511.9728 & $* * *$ & 18.77 \\
\hline Area $x$ Month & 55 & 66099 & 1202 & 11.2391 & $* * *$ & 11.33 \\
\hline Area x Year & 15 & 3829 & 255 & 2.3872 & $* *$ & 0.65 \\
\hline Area x Depth & 10 & 47600 & 4760 & 44.5148 & $* * *$ & 8.16 \\
\hline Month x Year & 33 & 6063 & 184 & 1.7183 & ns & 1.04 \\
\hline Month x Depth & 22 & 93241 & 4238 & 39.6356 & $* * *$ & 16 \\
\hline Year x Depth & 6 & 447 & 75 & 0.6967 & $\mathrm{~ns}$ & 0.07 \\
\hline Residuals & 701 & 74958 & 107 & & & 12.85 \\
\hline
\end{tabular}

